\title{
The impact of quantitative easing on UK bank lending: Why banks do not lend to businesses?
}

\author{
Mahmoud Fatouh $^{\mathrm{a}, \dagger}$, Sheri Markose ${ }^{\mathrm{b}, *}$, Simone Giansante ${ }^{\mathrm{c}}$ \\ a Bank of England, and Department of Economics, University of Essex, Threadneedle St, London EC2R 8AH, UK \\ ${ }^{\mathrm{b}}$ Department of Economics, University of Essex, Wivenhoe Park, CO4 3SQ Colchester, UK \\ ' School of Management, University of Bath, Claverton Down, Bath BA2 7AY, United Kingdom
}

\section{A R T I C L E I N F O}

\section{Article history:}

Received 1 May 2018

Revised 18 January 2019

Accepted 20 February 2019

Available online $\mathrm{xxx}$

\section{JEL classification:}

E51

E52

E58

G02

\section{Keywords:}

Monetary policy

Quantitative easing: bank lending

Agent-based modelling

Gilt yields

Capital adequacy requirements

Risk weighted assets

\begin{abstract}
A B S T R A C T
The growing proportion of UK bank lending to the financial sector reached a peak in 2007 just before the onset of the Global Financial Crisis (GFC). This marks a trend in the dwindling amount of bank lending to private sector non-financial corporations (PNFCs), which was exacerbated with the Great Recession. Many central banks aimed to revive bank lending with quantitative easing $(\mathrm{QE})$ and unconventional monetary policy. We propose an agent based computational economics (ACE) model which combines the main factors in the economic environment of $\mathrm{QE}$ and Basel regulatory framework to analyse why UK banks do not prioritize lending to non-financial businesses. The lower bond yields caused by QE encourage big firms to substitute away from bank borrowing to bond issuance. In addition, the risk weight regime of Basel II/III on capital induces banks to favour mortgages over business loans to small and medium enterprises (SMEs). The combination of lower bond yields and Basel II/III capital requirements on banks, which, respectively, impact demand and supply of credit in the UK, plays a role in the drop of bank loans to businesses. The ACE model aims to reinstate policy regimes that form constraints and incentives for the behaviour of market participants to provide the causal factors in observed macro-economic phenomena.
\end{abstract}

(c) 2019 Elsevier B.V. All rights reserved.

\section{Introduction}

The great financial crisis (GFC) of 2007 produced severe recessions in major economies and raised the threat of a total collapse of the global financial system. The crisis had major repercussions for the UK economy that witnessed an increase in unemployment and severe contraction in GDP by about $4.7 \%$ in the last 3 quarters of 2008. Like the monetary authorities of other countries, the Bank of England (BoE) reduced its short-term policy rate to exceptionally low levels from 5.75\% to $0.5 \%$, over the period from July 2007 to March 2009. However, lowering interest rates proved not to be sufficient to support aggregate demand and help in the economic recovery to pre-crisis levels. Consequently, following the precedent first set by the Bank of Japan in 2001, and more recently by the US Federal Reserve (Fed) Large Scale Asset Purchase (LSAPs) programs of November 2008, the BoE Monetary Policy Committee (MPC) launched an open-ended asset purchase program (APP) in March 2009. Unlike conventional open market operations involving short term assets, central banks make outright purchases

\footnotetext{
* Corresponding author.

E-mail addresses: mfatou@essex.ac.uk (M. Fatouh), scher@essex.ac.uk (S. Markose), s.giansante@bath.ac.uk (S. Giansante).

$\dagger$ The views expressed in this paper are solely those of the authors and do not represent those of the Bank of England
} 
(a)

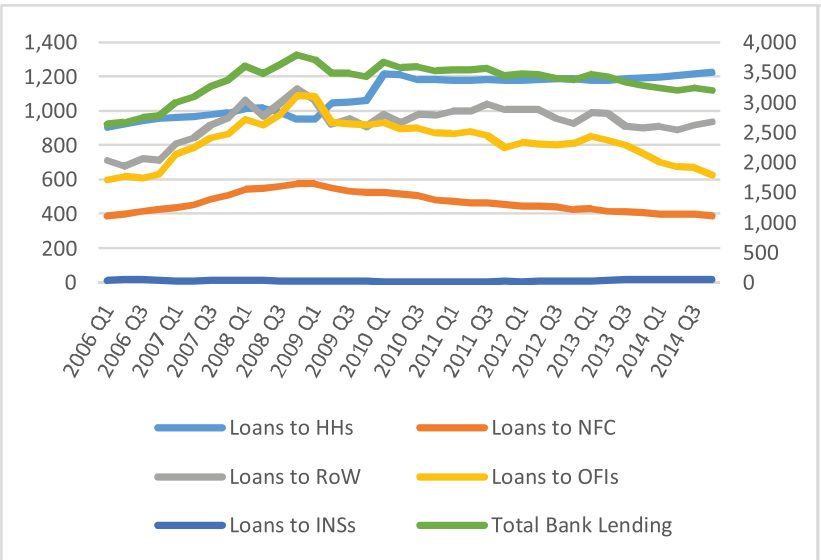

(b)

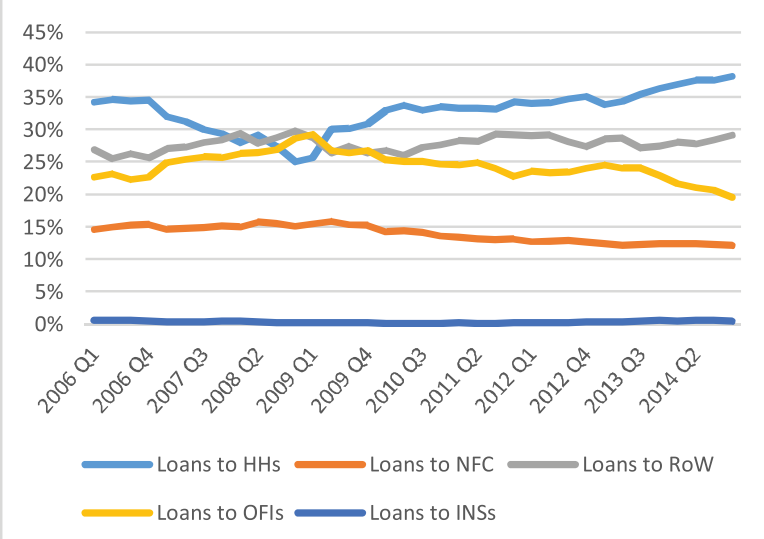

Fig. 1. UK bank lending to different sectors 2006 to 2014 (a) Amounts bank lending (£Billion, RHS Totals) (b) Proportions of total lending (\%). Notes: UK Bank lending refers to lending by monetary and financial institution (Totals on right hand side, RHS, Axis of Figure 1.a); RoW: Rest of World; HHs: Households; PNFCs: Private non-Financial Corporates; OFIs: Other Financial Institutions; INSs: Insurance Companies and Pension Funds. Source: UK ONS flow of funds project: financial accounts excel sheet 3.2 .

of longer term securities (see, Haldane et al., 2016) under these asset purchase programs, also referred to as quantitative easing (QE).

As the APP was to be subsumed under the 1997 Monetary Policy Framework, priority was given to the necessity of "increasing nominal spending growth to a rate consistent with meeting the inflation target in the medium term". ${ }^{1}$ In addition, the MPC minutes of March 52009 note that APP "would also mean that the banking system would be holding a higher level of reserves in aggregate, which might cause it to increase its lending to companies and households". At the same time, it was also anticipated by the MPC that APP will enhance "functioning of corporate credit markets, that should make it easier for some types of companies to raise finance, reducing their reliance on the banking sector" (Ibid.) The mechanics of QE aimed at asset purchases from non-bank financial institutions involves new electronic central bank money credited to the reserve account of the seller's bank which, in turn, creates a deposit of the same amount favouring the seller. This, so called bank lending channel, which is now replete with bank reserves, is expected to increase bank lending to households and businesses. ${ }^{2}$ To what extent were these anticipated outcomes of QE borne out?

As shown in Fig. 1(a) Amounts Bank Lending (£Billion, RHS Totals), UK total bank lending saw an average growth of 5.5\% per quarter between 2007 Q1 and 2008 Q1, with the latter standing at $£ 3.61$ Trillion, suffered falls in the 4\%-6\% range in the period between 2008 Q2-2009 Q2. Within a year from the start of the APP, total bank lending jumped 7\% in 2010 Q1 and the lending to households and private non-financial corporates (PNFCs) peaked at $£ 1.74$ Trillion. However, over the next 3 years, total bank lending fell by 1\%-3\% annually. It showed a fall or little to no growth in every quarter except for 2013 Q1, probably because of funding for lending scheme (FLS) (Churm et al. (2012), Badeley-Chappell (2013)). It should be noted that when bank lending to rest of the world (ROW) is accounted for, domestic lending fell by over $£ 200$ bn. Further, lending has been found to be skewed in the direction of mortgage lending to households with its share of total bank lending rising from $25.69 \%$ in $2009 \mathrm{Q} 1$ to $38.18 \%$ by the end of 2014. In contrast, non-financial corporations and SMEs faced a fall in bank loans with their share of total bank loans falling from $15.91 \%$ to $12.16 \%$ over the same period. One of the key drivers for this fall in total bank loans is the extent to which non-financial firms substituted away from bank loans to bond issuance through the portfolio rebalancing channel. As shown in Fig. 2, from the peak of about f600bn of bank loans in September 2008, PNFCs (both big firms and SMEs) experienced a reduction of about $£ 185$ bn of banks loans with some $£ 68.48$ bn of bond issues by big firms potentially replacing bank loans from March 2009 when APP commenced to April 2014.

A number of studies have investigated how QE policy influences the yield curve but lack details on how bank lending to the real economy contracted, especially, the lending to SMEs (see, Goodhart and Ashworth (2012)). Gagnon et al. (2011) emphasize the impact of the Fed LSAPs programs on the yields of the longer-term assets purchased under the programs. They point out that the programs appear to be successful in decreasing the term premiums by 30 to 100 basis points. More

\footnotetext{
${ }^{1}$ This is reported in the letter from the Chancellor of the Exchequer of 3 March 2009 and also in the MPC minutes of March 52009 (http://webarchive.nationalarchives.gov.uk/20091204142322/http://www.hm-treasury.gov.uk/d/chxletter_boe050309.pdf, and http://www.bankofengland.co. uk/publications/minutes/Documents/mpc/pdf/2009/mpc0903.pdf). The assets purchases are also seen to be critical to the strategy "to ease the flow of corporate credit... increase liquidity and trading activity in some UK financial markets and stimulate issuance by corporate borrowers and the resumption of capital market flows" (Ibid).

2 Regarding the targeting of non-bank financial institutions, especially Insurance Companies and Pension Funds, see point 42 in the minutes of the MPC meeting for the 4 and 5 March 2009 available at: http://www.bankofengland.co.uk/publications/minutes/Documents/mpc/pdf/2009/mpc0903.pdf.
} 


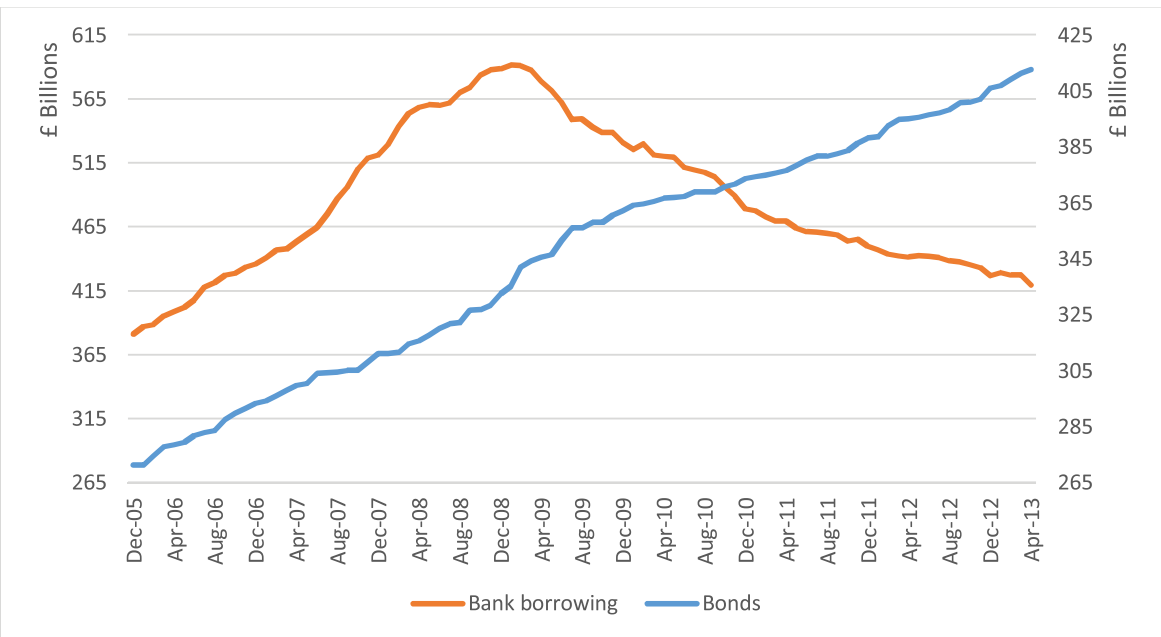

Fig. 2. UK PNFC Bond Stock (RHS, Blue) and PNFC Bank Borrowing (LHS, Brown) 2006 to 2014 (£Billion).

Notes: The variable CPMB29M is used for PNFC bonds with the stock of PNFC bonds valued at $£ 271.297$ bn from ONS is used for Dec 2005 . The variable LPMB4VR for PNFC bank loans is used from BoE interactive website.

Source: http://www.bankofengland.co.uk/boeapps/iadb/newintermed.asp.

comprehensively, Joyce et al. (2011) specify five transmission channels of the impact of QE. This includes policy signalling, portfolio rebalancing, liquidity, broad money, and confidence. They claim that while the effects of QE can spread directly into the wider economy through the confidence factor leading to larger aggregate expenditure, asset prices and returns represent the path of transmission for the other four channels. By lowering bond yields, QE can boost aggregate spending through decreasing the cost of borrowing for firms and consumers, Joyce et al. (2011). Joyce et al. (2014) have also investigated the specific mechanics of portfolio rebalancing by the non-bank financial institutional investors such as Life Insurance and Pension Funds, which substituted the assets purchased by the BoE with bonds issued by PNFCs. Equities price growth caused by a combination of portfolio rebalancing and falling interest rates also boosts the value of legacy assets held by financial institutions, a phenomenon that is referred to as "stealth recapitalization" (see, Brunnermeier and Sannikov (2014) and Chodorow-Reich (2014)) that can help banks to remain buoyant. Hence, notwithstanding the controversy surrounding the accumulation of 'excess' reserves at the central bank from APP (see, Reis et al., 2016), ${ }^{3}$ and concerns about such extremely loose monetary policy conditions for a prolonged period (see, Rajan (2010), Bean et al. (2015)) in the post GFC period, this paper investigates a specific misdirection of bank lending in the context of $\mathrm{QE}$ that has resulted in a fall in bank loans to the real economy.

While Office for National Statistics (ONS) data in Fig. 1(a) and 1(b) show that domestic lending by UK banks fell by more than £218.6 billion in four years after APP was introduced early in 2009, the worrying trend is the shrinkage in the amount of loans to UK non-financial businesses falling to as low as $12 \%$ of total lending when compared to a 50\% share of bank loans to financial companies and rest of the world. The latter two was as high as 59\% in 2008Q1. Indeed, this is part of a bigger problem of "why banks do not lend to the real economy". This has being discussed by several authors under the rubric of excessive growth of the financial sector in advanced economies and, in particular, growing bank activities relating to trading assets and financialization ${ }^{4}$ as these have a bearing on low GDP growth and its extreme volatility (Blundell-Wignall and Roulet (2013), Bezemer and Hudson (2016), Cecchetti and Kharroubi (2015), Arcand et al. (2015), Stockhammer (2004), Easterly et al. (2001)). The latter study by Stiglitz and his co-authors was one of the first to signal the negative impact of the excessive growth of the financial sector. Though highly relevant, the focus of our analysis is not on this wider problem, which also relates to banks' chase for yield and carry trades associated with cross-border bank lending triggered by prolonged low interest rates. Instead, this paper aims to reinstate at a micro-level the role of financial

\footnotetext{
3 Between March 2009 and August 2012, the total amount of bank reserves on the liabilities side of the BoE increased from about £31.5 billion to $£ 251.9$ billion. This increase in bank reserves at the BoE accounts for about 59\% the size of APP by the end of 2012. The same phenomena of increasing bank reserves at the central bank appears in the US where the reserve balances with Federal Reserve expanded massively after the launch of large scale asset purchase (LSAP) programs in 2008. The Fed data shows that bank reserves expanded by about 812\% between October 2008 and August 2012 . (Source: Data Download Program (DPD): http://www.federalreserve.gov/datadownload/).

${ }^{4}$ Partnoy and Eisinger (2013) analyse the financial statements of big banks and find that the majority of their income and also outsized losses come from traded assets. 
regulation, which Stiglitz (2011) raised as an urgent issue for incorporation into macro-economic models to test out systemic and systematic impacts from the incentives and constraints inherent to regulation. ${ }^{5}$

Noting the large literature on the fall in bank lending during recessions, including theories on the liquidity trap where close to zero interest rates cannot stimulate investment (for example Krugman et al. (1998) and Krugman (2000)), a relatively new strand of literature on the impact on bank lending from capital adequacy requirements has evolved since the 1990s. The diverse justifications for the decreases in bank lending during recessions in the presence of capital adequacy requirements have been based either on the lower supply of credit by banks or the lack of demand for loans. The supplyside explanations can be grouped into two main categories. Studies in the first category (such as Thakor (1996), and Borio and Zhu (2012), Angelini et al. (2015)) attribute the decrease in bank lending to the changes in the risk perception of the banks. ${ }^{6}$ The other category of explanations (for example, Watanabe (2007), Repullo and Suarez (2013), and Repullo (2013)) refers to the shortage of bank capital (the capital crunch hypothesis) as the main driver of credit rationing in the downturn especially in the presence of pro-cyclical capital regulations (see Brunnermeier et al. (2009)). ${ }^{7}$ Further, the seminal work of Jones (2000) implicates banks' regulatory capital arbitrage for prompting an individually rational but destabilizing and socially deleterious response to Basel capital requirements for which Jones claims econometric models may not be best suited to analyse. The perverse incentives of Basel II has been implicated for the large increase in leverage in banks with the use of credit default swaps (CDS) in addition to mortgage backed securities on bank balance sheets (Blundell-Wignall and Roullet (2013) and Markose et al. (2012)) and of sovereign debt to reduce capital from the implied risk weighting, respectively, in the carry trades associated with the GFC and in the Eurozone crisis (Acharya and Steffan (2015)). Following the Jones (2000) precedent, we argue that an agent based model of bank lending is needed to show how the constraints and incentives of the risk weighted capital requirements of Basel II and III have a direct bearing on the direction of the bank lending, favouring mortgages and penalizing, in particular, SMEs.

In summary, our agent based model brings together the supply and demand sides of bank lending in granular detail. On the demand side, the influence of APP on gilts and corporate bond yields represents the exogenously given starting point of our ACE model. Asset purchases by BoE reduce the supply of gilts remaining for the private sector (local supply effects) leading to lower yields on gilts and corporate bonds (McLaren et al. (2014)). The lower bond yields induce BFs to substitute parts of their bank borrowing with security debt (bonds). On the supply side, influenced by the capital requirements, that assign different risk weights for different types of loans, banks respond to the drop in big firm borrowing, by expanding mortgages and decreasing the amount of loans granted to SMEs, which carry a higher risk weight. The mortgage market of UK households is also modelled in detail. The distinction between big firms (BFs) and SMEs is important in the context of this paper because the accessibility to debt financing is different for the two types of firms. BFs have access to debt security (bond) market, whereas borrowing from banks represents the sole source of debt financing for SMEs. In the standard perspective of the fall in the demand for loans, for instance, Bikker and Hu (2012) argue that the lack of demand for bank loans rather than supply is the key factor in the fall in bank borrowing during slumps. ${ }^{8}$ However, in this context, little consideration has been given to the impact of lower bond yields (and hence the wider use of debt security) which is caused by $\mathrm{QE}$, on the demand for bank loans by big non-financial firms. This represents a vital element in our explanation of the fall of bank lending to non-financial businesses. We argue that a detailed model rich in regulatory bank capital constraints is needed to show how the slack caused in the bank loan portfolio rebalancing by big firms in favour of bonds post APP impact on yield curves helped expand UK loans for mortgages at the expense of loans to SMEs.

Methodologically, we propose a data driven formulation of the ACE model of the developments in the UK bank lending markets since APP was introduced along with the regulatory capital constraints on banks. We follow the data driven approach described in Markose (2013) in requiring that the distributional characteristics of the different economic sectors, such as households, non-financial businesses and banks, are based on empirical data. We implement an important empirical scale factor to specify the numbers of agents in each class in order that they represent the UK economy. This also permits the outputs of the ACE model to be scaled back up to give simulated results that can be validated against actual UK data. We use Windrum et al. (2007) method for ACE model validation.

The relevant balance sheet items of each of the 10 biggest UK banks is part of the initial conditions for the simulation of UK bank lending decisions for mortgages and to SMEs. The use of micro-level data sets is similar to the BoE agent based model of the UK mortgage market, Baptista et al. (2016), in that granular institutional details and data are included to investigate implications of specific macro-policy relevant measures that can alter behaviours of market participants by using the simulation model for scenario analysis and comparative statics. However, while the BoE ACE focusses on the buy to let rental market, we consider a wider loan portfolio decision model of UK banks. The important difference in banks' behaviour

${ }^{5}$ Stiglitz (2011), in the context of fixing macroeconomics in the post GFC era, has noted that certain 'perverse' incentive structures especially in the financial sector were instrumental for the destabilizing events of the GFC. Stiglitz (ibid) concludes that .. "the standard macroeconomic models neither incorporated them nor provided an explanation for why such incentive structures would become prevalent-and these failures are failures of economic science."

${ }^{6}$ However, as noted by Goodhart and Ashworth (2012), relevant factors such as default rates that affect the risk premia of different loan types, especially in market downturns do not feature in DSGE models. In the latter only the risk free policy rate matters.

7 The reliance of capital regulations on the mark-to-market valuations of assets and the market-based measures of risk makes these regulations procyclical and increases the volatility in asset markets. That is, the increases in market value of equity during booms accompanied with fixed costs of bank regulations induce banks to expand their lending. In contrast, during busts equity prices become low, decreasing the ability of banks to provide loans. For a further discussion of the pro-cyclicality of bank regulations see Brunnermeier et al. (2009).

8 See also, Berger and Udell (1994). 
with the introduction of Basel capital constraints in their portfolio allocation decision, comes about only when in addition to the direct costs of the credit risk of default on loans, the different categories of bank loans invite an institutionalized cost of capital implied by the Basel risk weight rule. We use data on bank write offs for each of the three categories of loans to proxy for the probability of default on the respective loans. The simple $8 \%$ capital ratio of Basel I, results in exactly the same optimal lending policy for banks as in the scenario of no regulatory capital requirements with the former implying an overall upper limit on leverage for the total loan book, and a potential contraction of this, but without distinction between the asset classes. In contrast, one of our main findings is that what was a less than rigid preference among banks in favour of mortgages and against loans to SMEs, has become a veritable mecca of what Jordà et al. (2016) have called 'mortgaging up' after the introduction of favourable risk weights on mortgages in Basel II. Of course, there has not been the aggressive capital arbitrage by banks either through remote or synthetic securitization (see, Blundell-Wignall and Roulet (2013)) in the post 2009 period of APP. Our results are consistent with the empirical findings that during the course of APP, the assumption that banks extended mortgages only in response to the slack caused by big firms reducing bank loans as bond yields fell, is a good one. Indeed, Section 4.2 shows that this expansion in mortgage loans by UK loans under Scenario 3 Basel II/III risk weight rules came at the expense of loans to SMEs. Further, the growth of UK mortgage lending was not sufficient to counter the decline in business loans, thereby representing the main cause of the shrinkage in total bank lending.

It is envisaged that the data driven agent based model of the UK banking sector will be extended in a modular fashion to encompass a more explicit characterization of the Brunnermeir and Sannikov (2012) stealth recapitalization of banks in low interest rate regimes that fuel a financial asset price boom and also the search for yield carry trades involving emerging market countries financed by UK banks. An additional ACE extension is needed to fully model big PNFC behaviours regarding their option to use funds from bond issuance to buy back shares or repay loans, which is beyond the scope of the current model which is focussed on the bank lending channel. ${ }^{9}$ As will be explained in the literature survey, though not fully exploited yet, this category of ACE models which we called 'modular plug-ins' can be built via extensions that alter the endogenous/exogenous demarcation, viz. by endogenizing or modelling more elaborate behaviours (rather than just an if -then- rule) for agents in certain sectors that were considered to be exogenous in the extant ACE model. The ACE approach can do this better than other modelling techniques with the modeller creating exogenous data feeds to the model agents in a time specific way while focussing on specific behaviours and not others.

The reminder of the paper is structured as follows. Section 2 surveys the relevant literature. The agent-based approach used in the paper is outlined in Section 3 along with a full description of the model agents and their behaviours. Section 4 summarizes the ACE model initial conditions followed by the simulation outcomes and model validation results. Section 5 contains concluding remarks of the paper.

\section{The related literature}

This literature survey is divided into three subsections. The first gives a brief survey of the QE literature including that related to the Japanese QE introduced in 2001. The second section examines some of the main papers in the field on the impact of capital adequacy requirements on bank lending, especially, in recessions. In the last section, the literature of agent-based computational macroeconomics (ACME) is reviewed.

\subsection{The impact of quantitative easing on bank lending}

Quantitative easing (QE) has been stimulating the academic literature since its introduction by the Bank of Japan (BoJ) in 2001, and in particular post GFC when the monetary authorities of the US, UK and EU started to pursue unconventional monetary policies. The main studies on QE focused on the influence of the massive asset purchases on asset yields and less so on the macroeconomic consequences and the impact on bank lending. First, while authors agree that asset purchases under QE have decreased the yields of government bonds (Kimura and Small (2007) for Japan, D'Amico and King (2013) for the US, and Daines, Joyce and Tong (2012) for the UK), the evidence on the impact on other assets yields has been mixed. Kimura and Small (2007) point out that BoJ asset purchases led to lower premiums on higher grade corporate bonds. This conclusion is supported by McLaren et al. (2014) who argue that asset purchases under APP reduced gilts yield and, through local supply effects (asset purchases by BoE reduce the supply of gilts remaining for the private sector), the yields of corporate bonds. They claim that the expected asset purchases had a significant impact on yields after each announcement in March 2009, August 2009, and February 2012. Similar results for Fed's LSAP programs are revealed by Gagnon et al. (2011). They show that the programs led to drops of 30 to 100 basis points in the risk premium component (rather than expectation component) of the longer-term yields. Conversely, Oda and Ueda (2007) show that the BoJ monetary policy at close to zero interest rate was effective in lowering the expectations component of interest rates. However, the portfolio rebalancing effects on the risk premium component were not significant.

The papers that analyse the effects on the wider economy generally specify a positive influence of $\mathrm{QE}$ on the real economy. For instance, Honda, Kuroki, and Tachibana (2013) and Harada and Masujima (2009) indicate that BoJ QE in-

\footnotetext{
${ }^{9}$ That funds from bond issuance have also been used to buy back shares by US and UK companies has been highlighted in the financial press (see Reuters, Sept 2013, Yahoo Finance 2016, Washington Post, 2018) and by academics (see Gordon (2018), Fried and Wang (2018)) as a matter of great concern about the malaise relating to stock market bubbles, corporate indebtedness and slow growth.
} 
creased aggregate output through asset prices and bank reserves. This conclusion is supported by the results for US QE (Chen et al. (2011) and Baumeister and Benati (2013)) and UK QE (Kapetanios et al. (2012)). However, the mechanics of bank lending in response to the QE program has received relatively less attention. For example, Bowman et al. (2011) identify a positive but small impact of BoJ QE on bank lending. Joyce and Spaltro (2014) show similar outcomes for the BoE APP program. They claim that the effects were more important for smaller banks.

\subsection{Bank lending and capital adequacy requirements}

The influence of capital requirements on bank lending and bank behaviour has been investigated since the introduction of Basel rules in the late 1980s. Thakor (1996) inspects the role played by Basel capital rules in the developments in the US banking system in the early 1990s including the fall in aggregate bank lending and the increase in the share of government debt securities holding in the portfolios of US banks. He indicates that an expansionary monetary policy in the presence of capital requirements may either increase or decrease bank lending depending on the impact of the increasing money supply on the term structure of the interest rates. The view that weakly capitalized banks tend to substitute away from assets with higher risk weights and cut their total lending to enhance their capital ratios is supported by several authors. ${ }^{10}$ Gambacorta and Marques-Ibanez (2011) who specify that banks, with weaker capital ratios and greater dependence on market funding and non-interest income sources, strongly decreased their lending during the crisis. Moreover, Heid, Porath and Stolz (2004) results show that a fall in capital buffers induces banks to rebuild them by raising capital and lowering risk-weighted assets by investing more in the safer assets and less of the riskier assets. However, although most of the literature focuses on the role of the supply of credit, some studies attribute the decreases in bank lending in recessions to demand factors. Berger and Udell (1994) investigate the causes of the reallocation of credit by U.S. commercial banks from loans to securities in the early 1990s. Their results indicate that while risk-related credit crunch hypotheses are not salient reasons for the fall in bank lending, demand-side impact on lending tend to be strong. More recently, Bikker and Hu (2002) argue that credit rationing in a cyclical downturn is not driven by a shortage in bank capital as the capital crunch hypothesis suggests. They show that while the demand factors dominate the market, the preeminent loans supply variables (bank capital and reserves) tend to be insignificant determinants of bank lending.

As many of these papers rely on econometric analysis, conclusions such as weakly capitalized firms switch to lower risk weighted assets is highlighted as an individually rational thing to reduce capital requirements, few papers take this forward as part of the macro-economic framework. Despite an influential survey of Furfine et al. (1999) that asks hard questions regarding whether the Basel regulatory framework led to systematic trends in bank lending and in particular the role of perverse incentives flagged out in detail in Jones (2000) in the form of capital arbitrage, few macroeconomic models aim to include the incentives and constraints posed by Basel rules for the macroscopic implications of this for the wider problem that banks are lending less and less to non-financial corporations, especially to SMEs. As noted in the introduction, this paper follows this route. In Markose et al. (2012), an agent based model similar in the data driven formulation of the model in this paper, found that the big US banks were involved in a CDS carry trade in the run up to the 2007 GFC, but without the favorable $20 \%$ risk weight from synthetic securitization that permitted banks to reduce capital from $8 \%$ on bank assets to $1.6 \%$ with the $20 \%$ risk weight that follows from the adoption of credit risk transfer by holding of CDS from AAA guarantors (like AIG), the extremely high levels of leverage on balance sheets of US FDIC big banks could not have been achieved. Likewise, Acharya and Steffan (2015) gives the following analysis for the Eurozone crisis as a case of regulatory capital arbitrage due to Basel II regulations, which assign a zero-risk weight for investments in sovereign debt. They argue that governments themselves could have had incentives to preserve the zero-risk weight in order to increase demand for high risk sovereign debt. Acharya and Steffan (2015) state that "Undercapitalized banks, that is, banks with low Tier 1 capital ratios, have incentives to increase short-term return on equity by shifting their portfolios into the highest-yielding assets with the lowest risk weights in an attempt to meet regulatory capital requirements without having to issue economic capital (regulatory capital arbitrage)". As will be pointed out in the next section, an ACE model is well placed to test out perverse incentives that lead to destabilizing effects of policy.

\subsection{Agent-Based computational (ACE) macroeconomics}

The study of the economy by means of ACME and network analysis is a relatively new field. It also represents a suitable approach to respond to the criticisms of the generic representative agent model of mainstream macroeconomic models. ${ }^{11}$ Macroeconomists have been accused of a heavy dependence on dynamic stochastic general equilibrium (DSGE) models that are built around special cases where market inefficiencies are not possible (Stiglitz (2011)) and institutional details and financial interconnections in the provision of liquidity, capital adequacy, solvency and contagion based negative externalities are ignored (Markose (2013)). Critics of the standard macro models have targeted the equilibrium assumption that not only nets out all private credit, these models cannot incorporate herd behaviour and network effects, Akerlof (2002), and also carry trades from perverse incentives that result in destabilising phenomena in the real world, Colander et al. (2009).

\footnotetext{
${ }^{10}$ For example, Gambacorta and Mistrulli (2004), Rime (2001), and Furfine (2000).

11 DelliGatti et al. (2008, 2010), Arthur (2006), Buiter (2009), Wieland (2010), Stiglitz (2011), Kirman (2006, 2010), Collander et al. (2009), among others.
} 
For our purposes existing ACME models can be classified into two main categories: those that produce qualitative results and those that are data driven. The bulk of the ACME involves qualitative models in which stylized boom bust dynamics are produced. This can be done by relaxing rational expectations and using adaptive learning or explicit herding behaviours (see Gaffeo et al., 2008). Lengnick (2013) gives a simple baseline model. A recent survey of the ACEME is given in Dawid and Delligatti (2018).

In the second category of ACME, we have those purported to represent massive real economy models. Models such as EURACE and ASPEN projects attempt to, respectively, simulate the entire EU and US economies. These models have been used to investigate the impact of policy interventions in the US and the Euro Area. For example, Teglio, Raberto and Cincotti (2012) use the EURACE environment to assess the impact of capital adequacy requirements on the wider economy. They perform simulations over a 40-year period and examine the short, medium and long run implications of different levels of capital adequacy ratios. Their results show a non-trivial impact of capital adequacy ratios on GDP, the unemployment rate and the aggregate capital stock. They also point out that this influence of the capital adequacy ratios arises from the credit channel, and varies significantly depending on the time span of the evaluation period.

The subset of the data based ACE and the most recent category, including the model of this paper, follow the approach suggested by Markose (2013) and it is closest in spirit to the BoE agent based model for the UK mortgage market of Battista et al. (2016). The specificity of institutional details and policy conditions are finely modelled to analyze the responses of the relevant economic agents. Micro level data sets for the economy are used to calibrate the model agents and flow of funds constraints are strictly adhered to. In other words, the endogenous/exogenous demarcation can be made in ACE models with the relevant exogenous empirical data that can be specified as 'data agents' can feed into or inform the model agents in ways specified by the modeller. In Markose et al. (2012), the ACE model was used to see the consequences of the credit risk transfer rule in Basel II that gave a $20 \%$ risk weight to bank assets that had AAA guarantors providing CDS cover. It is argued that rule following behaviour as in complying with the regulation and availing of the full extent of its incentives, and also the conduct of carry trade activities are relatively easy to implement in ACE. This is because unlike fully fledged adaptive behaviour, agents' strategies, intelligence and autonomy are limited to following the letter of the law and strictly verifying conditions for which the most profitable arbitrage applies and also tracking the resulting self-reflexive deterioration of the risk in bank assets as agents herd into them. Stress tests for perverse incentives of policy are among the easiest of multi-agent exercises and it should be de rigueur in macro-prudential policy in order that flawed policies do not get perpetuated.

\section{Methodology of data driven Agent-based model of UK bank lending}

\subsection{Data characteristics of agents}

We model the developments in bank lending in the UK after the introduction of APP in 2009 using an ABM with four classes of agents: households (HHs), big firms (BFs), small and medium enterprises (SMEs) and banks (Bs)). The UK economy data for each of these classes of agents around the launch of APP in 2009, described below and also in the Appendix, is used as empirical basis of the initial conditions both for the numbers of agents in each class and also for relevant balance sheet data of agents for the ACE model. The latter is purported to simulate agents' interactions in the UK bank lending markets on a monthly basis for a period of 50 months from the advent of the BoE APP in 2009 .

Our approach can be divided into five main steps. Firstly, our data driven ACE methodology is innovative in proposing a scale factor for the ABM and the real economy. The size of agent classes is set in a way that replicates the actual sizes of agent populations in the UK based on data from the ONS, BoE financial statistics, Nationwide, and The Money Charity around the launch of APP in March 2009.We implement a proportional scaling factor calculated using the actual sizes of the UK households and nonfinancial business populations as follows. The number of households with at least one adult working in 2009 was 21.46 million. ${ }^{12}$ Additionally, in 2009 there were 4.923 million businesses, 99.9\% (i.e. 4.918 million) of which were SMEs ${ }^{13}$ and the remaining (i.e. 0.005 million) were BFs. This indicates proportions of 0.229 and 0.00024 between the number of SMEs and BFs, respectively, and the number of HHs. Hence, since the number of HHs in the ABM is set to 100,000 , the numbers of SMEs and BFs will be set to 22,900 and 24, respectively. As for banks, the data on 10 largest UK banks that account for over $87 \%$ of bank lending is used.

We will briefly describe how the incomes of the $100,000 \mathrm{HHs}$ in the ABM are set to represent the UK income distribution for 2009. This is needed for the purpose of modelling HHs' mortgage affordability used by banks as a lending criterion. We simulate the income distribution for the 100,000 model household agents from the UK income distribution given in deciles in Fig. 3 below from the Department of work and Pensions. We combine the data from the latter with that from the Institute for Fiscal Studies (IFS). ${ }^{14}$ IFS estimates the average weekly income of a household in the 2008-09 financial year as $£ 560.64$

\footnotetext{
12 In 2009, there were 25.83 million households where $16.9 \%$ of them were without work (i.e. with no adult working). The model assumes that only households with a working adult are eligible for mortgages to buy houses.

13 Small and Medium Enterprise Statistics for the UK and Regions; Enterprise Directorate; The Department for Business, Innovation and Skills (BIS); Available at: http://webarchive.nationalarchives.gov.uk/20110920151722/http:/stats.bis.gov.uk/ed/sme/index.htm.

14 Institute for Fiscal Studies: Inequality and Poverty Spreadsheet which "provides data on British living standards, inequality and poverty" available at: http://www.ifs.org.uk/tools_and_resources/incomes_in_uk.
} 


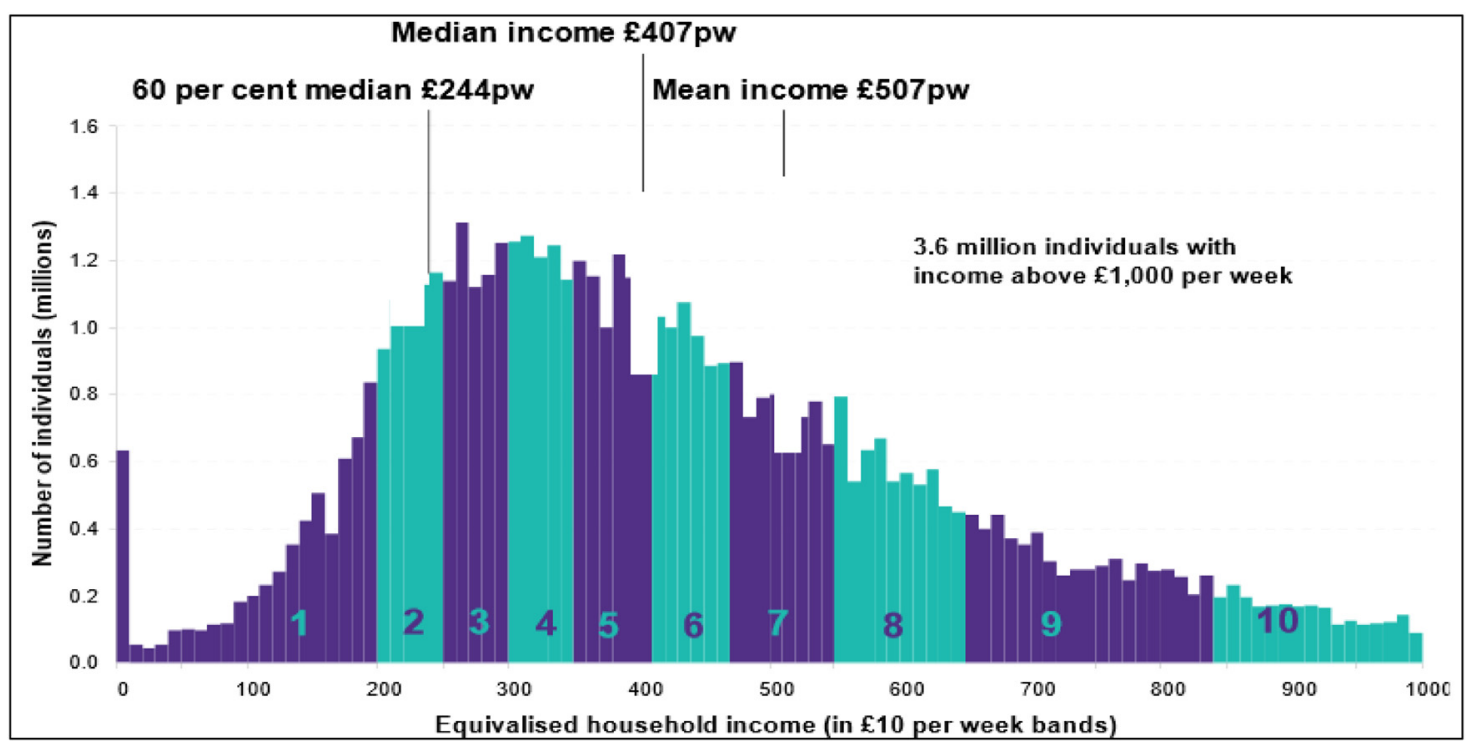

Fig. 3. The probability distribution of household weekly income (2008-09).

Source: Households below average income (HBAI): 1994/95 to 2008/09; P.15; Department for Work and Pensions; Available at: https://www.gov.uk/government/statistics/households-below-average-income-hbai-199495-to-200809.

(an equivalent of $£ 2429.43$ per month ${ }^{15}$ ) with $50 \%$ of the households making $£ 450.52$ or less a week (or $£ 1951.84$ a month) and about 3.6 million or $16.7 \%$ of households earning over $£ 1000$ per week (or $£ 4333.33$ per month). Note, for purposes of modelling HHs mortgage affordability used by banks as a lending criterion, we use the deciles given in Fig. 3 below based on the monthly equivalents of the weekly income data.

ONS home ownership and renting data ${ }^{16}$ indicates that $64 \%$ of homes in the UK are owner-occupied (the remaining $36 \%$ of homes are rented), and that about $52 \%$ of the homeowners have mortgage obligations. This yields the probability distribution for the number of houses per household in the initial period as follows. Of the $64 \%$ of home owners, we assume an equal $16 \%$ probability that they can own up to 4 additional houses. The value of the average UK mortgage peaked at about $£ 50,000$ in $2007 \mathrm{Q} 4$ and then fell below $£ 48,000$ in $2010 \mathrm{Q} 2$, taking 4 years till 2013 to recover to the pre-crisis peak. The UK average house price peaked at about $£ 180,000$ in $2007 \mathrm{Q} 2$, which then fell to below $£ 158,000$ in $2008 \mathrm{Q} 4$ and then recovering to the pre-crisis peak by 2014 Q1. ${ }^{17}$

Second, each agent is given a balance sheet representing its initial conditions in 2009 Q1. ONS data indicates that cash holdings of households represented about $14.43 \%$ of their total assets at the end of $2008^{18}$ while the cash holdings of nonfinancial businesses at that date represented about $12.83 \%$ of their total assets. At initial date BFs and SMEs are respectively assigned bank loans averaging $31.87 \%$ and $40 \%$ of their total liabilities, while BFs are shown to have bond stock valued at $19.79 \%$ of their total liabilities. BFs are assigned physical capital by using a uniform distribution over the range of $£ 5$ million to $£ 100$ billion of physical capital. We take the ONS data for 2009 for UK Gross Capital Stock, ${ }^{19}$ which is $£ 2202.6$ billion and therefore has an average value of about $£ 447$ million for the 4.923 million UK businesses. Hence, our distribution implies big firm capital to be highly skewed with over $50 \%$ of BFs with capital in excess of £50bn. In contrast, we assume the SME physical capital distribution to range from $£ 50,000$ to $£ 1$ million. Finally, in the case of data for banks, the exact relevant items of the balance sheets of the 10 largest UK banks in 2009 (see Appendix Fig. A2) are used.

In step three, households and non-financial firms are allocated to the 10 banks using relevant probability distributions. For instance, each of the UK banks is assigned 10,000 households as customers, distributed according to the income deciles given in Fig. 3 using monthly equivalents. Likewise, a similar distribution is made for BFs and SMEs as customers of the 10 UK banks. The 10 banks then receive a horizontal sum of deposits and make loans based on the above customer assignment.

In the fourth step, the behavioural rules of the agents are defined. This constitutes the main engine of the ABM and is described in detail in Section 3.2. These rules describe the responses of the agents to different developments. For instance, a

\footnotetext{
15 Monthly income = Weekly Income x 52 (weeks a year) / 12 (months a year).

16 This can be found at http://www.ons.gov.uk/ons/rel/census/2011-census/detailed-characteristics-on-housing-for-local-authorities-in-england-and-wales/ short-story-on-detailed-characteristics.html.

17 Source: Nationwide House Price Index (http://www.nationwide.co.uk/about/house-price-index/download-data\#xtab:uk-series).

18 This is calculated by taking the ratio of the sum of households' currency and deposits ( $£ 1,172.47$ billion) with the sum of households' financial liabilities and net worth at the end of 2008 ( $£ 1,550.13$ billion and $£ 6,573.64$ billion,respectively). The latter two yield the total assets of the household sector from the ONS Sectoral Financial Accounts.

19 This can be found at https://www.ons.gov.uk/economy/nationalaccounts/uksectoraccounts/datasets/capitalstock.
} 


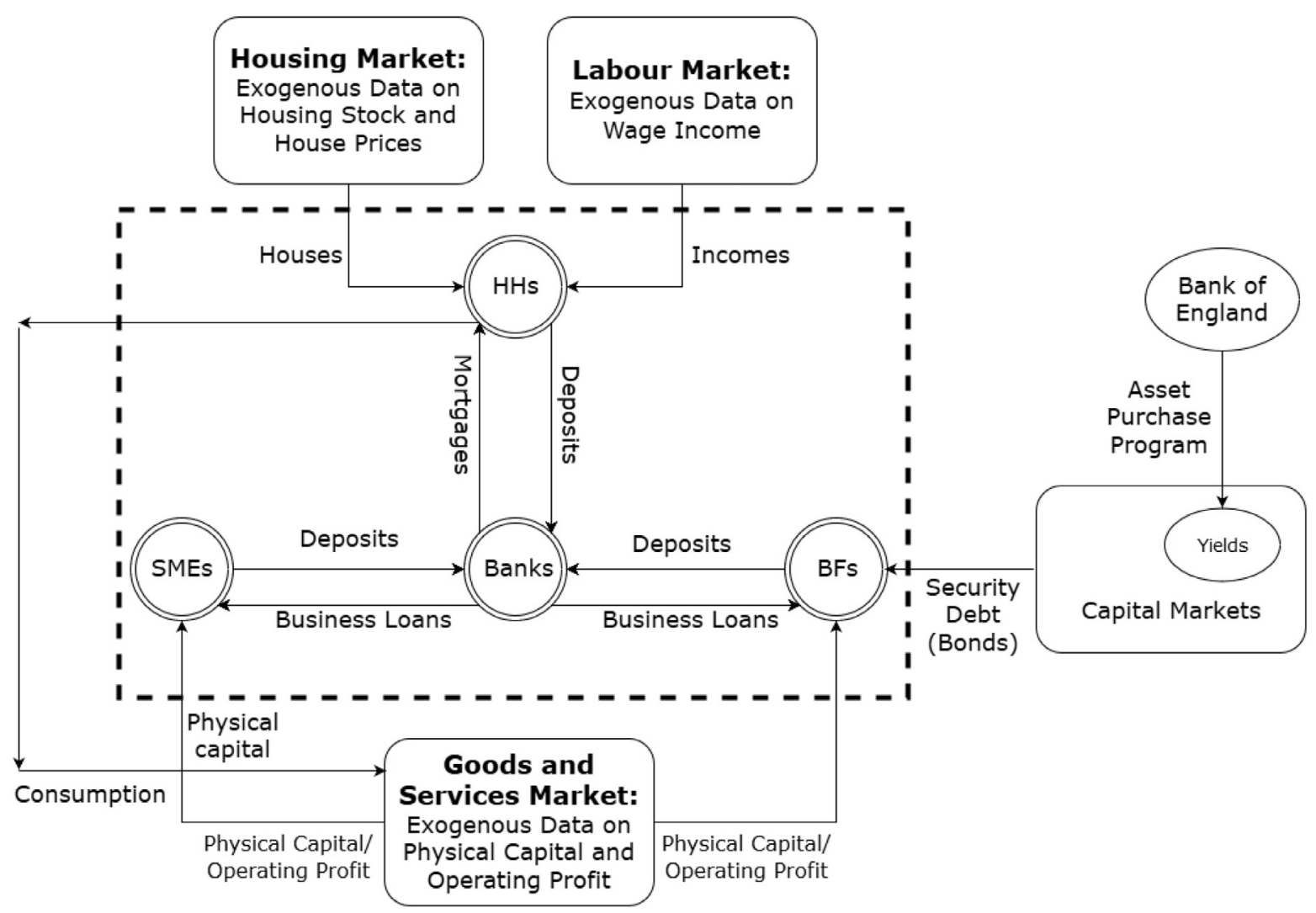

Fig. 4. Representation of the Agent-based Model of UK Bank Lending.

Notes: The components inside the dashed area correspond to agent behaviours that are endogenous, while the data for the rest will be supplied exogenously. The latter includes asset yields, the income and consumption expenditure of households, house prices, the physical capital and operating profits of businesses. HHs: households; BFs: big nonfinancial companies; SMEs: small and medium enterprises.

big firm responds to a fall in the cost of bond issuance by replacing part of its bank loans with bonds. Then, in the fifth step of the process, 50 simulations are run for the three different scenarios for bank behaviour to investigate the role played by Basel capital adequacy rules in conjunction with the BF response to falling bond yields with APP. At the end of this stage, the values of bank lending aggregates to households and nonfinancial businesses are simulated for each of the 50 months. Finally, the simulated bank lending aggregates are rescaled up and compared to the actual UK bank lending aggregates for purposes of model validation.

\subsection{The ACE model}

The model of this paper outlined in Fig. 4 has an the endogenous segment (the dashed area in Fig. 4), which is embedded within the wider economy where the relevant variables relating to the central bank, labour market, goods and services market, housing market, and capital markets are taken to be exogenous.

Following the assignment of non-bank agents within the endogenous dashed segment as customers of banks, both banks and non-banks make their respective decisions whilst responding to the exogenously given data from outside the dashed segment in Fig. 4. HHs and businesses deposit cash in their assigned banks. HHs and businesses also seek to obtain mortgages and bank loans, respectively, as conditions permit from their assigned banks. This implies that the assets and liabilities in the balance sheet of any bank are the horizontal sums of the corresponding assets and liabilities in the balance sheets of the agents who are assigned to this bank. For example, the amount of deposits on the liabilities side of a bank's balance sheet is the sum of the deposits of all HHs, BFs, and SMEs who are the customers of this bank.

Nonfinancial firms (BFs and SMEs) employ physical capital and cash to operate and finance their operations using a mixture of debt financing and equity. The amount of initial physical capital (and total assets) briefly described above and in the Appendix defines the firm's size which, in turn, determines its accessibility to different debt markets. While SMEs are restricted to bank borrowing, BFs can also issue debt securities. Banks accept deposits of HHs, BFs and SMEs, and provide loans in the form of mortgages to households and business loans to BFs and SMEs. A further description of the initial conditions of the agents and the behaviour of these agents over the simulation period will be presented in the next sections. 


\subsection{Agents' behaviours}

This section will set out the responses of the model agents to the developments in their surrounding environment and the subsequent interactions of one another within the endogenous segment of Fig. 4. According to Daines, Joyce and Tong (2012), the first round of BoE purchases caused a 100 basis points fall in gilts yields. Hence, the impact of BoE's APP is introduced into the model by allowing gilts rate to decrease by 2.5 basis points each period. This fall in gilts yield accompanied by the low policy rate results in changes in the relative cost of corporate bonds and consequently has significant implications for BFs. The reaction of banks to this fall in BFs' borrowing depends on the capital adequacy regime in operation. Hence, the behaviour of banks is investigated under three scenarios that reflect three possible capital requirements regimes. The latter influences the lending behaviour of banks to households and SMEs.

\subsubsection{Households behaviour}

We assume each household earns an income and accumulates its wealth at each period only in the form of houses and cash deposited with its assigned bank. The demand for mortgages is governed by HH incomes. It is assumed that HHs' incomes fluctuates by $0.275 \%$ each month in line with inflation between March 2009 and March 2013 as average annual inflation rate in the UK was $3.3 \%$ during that period.

$$
H H I_{i, t}=H H I_{i, t-1} \times\left(1+\frac{0.033}{12}\right)
$$

Here, $H H I_{i, t}$ is the income of household $i$ in period $t$.

We assume that HHs keep constant their expenditure habits of spending between $66 \%-70 \%$ of income on consumption. ${ }^{20}$ The remaining $30 \%-34 \%$ of income is added to $\mathrm{HH}$ cash reserves, which are used to pay the mortgage obligations (mortgage principal and interest) and to cover the deposit if a new mortgage is obtained. Denoting housing wealth of household $i$ in period $t$ as $H H H_{i, t}$, it can grow only with a new house purchase based with the allocation of a new mortgage denoted by, $N M_{i, t}$, to household $i$ in period $t$ with a $5 \%$ loan to value ratio in the benchmark simulation:

$$
H H H_{i, t}=H H H_{i, t-1}+\frac{1}{0.95} \times N M_{i, t}
$$

The conditions regarding whether a HH makes a mortgage application and the acceptance of the same by the bank it is assigned to, is determined in part as follows. A HH who is a first time buyer is given a higher probability of making a mortgage application of $30 \%$ compared to that of a $20 \%$ probability for those who already own one. In the eligibility criteria, $\mathrm{HH}$ disposable income or cash at time after mortgage payments is denoted as $H H C_{i, t}$, and $M P_{i, t}$ is the mortgage repayment made by household $i$ to their bank in period $t$. This is given in (3), with $P P_{i, t}$ and $I P_{i, t}$, respectively, denoting principal and interest parts of the mortgage payment and given in (4).

$$
\begin{aligned}
& H H C_{i, t}=H H C_{i, t-1}+0.3 H H I_{i, t}-\frac{0.05}{0.95} N M_{i, t}-M P_{i, t} \\
& M P_{i, t}=P P_{i, t}+I P_{i, t}
\end{aligned}
$$

Here, mortgage principal repayments and interest payments are calculated as in (5) and (6).

$$
\begin{aligned}
& P P_{i, t}=\frac{0.95}{360} \times N o M_{i, t} \times H P_{t-1}, \\
& I P_{i, t}=\frac{r_{H H, t-1}}{12} \times H H M_{i, t-1}
\end{aligned}
$$

Note, $H P_{t}$ : house price in period $t$; $N o M_{i, t}$ : the number of mortgages owed by household $i$ in period $t$; $H H M_{i, t}$ : the mortgage indebtedness of household $i$ in period $t ; r_{H H, t}$ : interest rate on mortgages in period $t$. In Eq. (7), we denote $M E \lg _{i, t}$ as the indicator for mortgage eligibility of household $i$ in its application for a new mortgage in period $t$ and $M A v_{b(i), t}$ is an indicator for new mortgages which determines whether the bank assigned to household $i$ is willing to lend. The value of this indicator will be derived from the bank behaviour described below. These minimum requirements employed by the banks are given in (7). To obtain a new mortgage, banks require the applicant $\mathrm{HH}$ to have a disposable income, $H H C_{i, t-1}$, that is at least twice the down payment or the deposit $\left(5 \%\right.$ of the house price $\left(0.05 \times H P_{t}\right)$ and have no more than 5 mortgages. Further, mortgage payment in the coming month should be no more than $40 \%$ of $\mathrm{HH}$ income, viz. $M P_{i, t+1} \leq 0.4 \times H H I_{i, t}$ in (7).

$$
M E l g_{i, t}=\left\{\begin{array}{cc}
1 & \text { if } H H C_{i, t-1} \geq 2 \times 0.05 \times H P_{t} \text { and } M P_{i, t+1} \leq 0.4 \times H H I_{i, t} \text { and } N o M_{i, t-1}<5 \\
0 & \text { Otherwise }
\end{array}\right\}
$$

${ }^{20}$ This is in keeping with the UK consumption to GDP ratio. In 2009 this was around 66.134\%, see https://data.worldbank.org/indicator/NE.CON.PETC.ZS? locations $=\mathrm{GB}$. We randomly assign the 100,000 households to have a consumption to income ratio in the range of $66 \%-70 \%$. 
Thus, the value of the new mortgage, $N M_{i, t}$, is given in (8) as the house price less deposit if the conditions in (7) are met under the provisothat the bank is able to do so.

$$
N M_{i, t}=\left\{\begin{array}{ll}
H P_{t} \times(1-0.05) & \text { if } M A v_{b(i), t}=1, M E \lg _{i, t}=1 \\
0 & \text { Otherwise }
\end{array}\right\} .
$$

Eq. (10) gives the HH net worth or equity at time t, $H H E_{i, t}$, as its housing wealth plus cash assets less mortgage debt, $H H M_{i, t}$, which is defined in (9) as the mortgage debt in period t-1 less principal and interest payment in t plus new mortgage at $\mathrm{t}$ :

$$
\begin{aligned}
& H H M_{i, t}=H H M_{i, t-1}-P P_{i, t}+N M_{i, t} \\
& H H E_{i, t}=H H H_{i, t-1}+H H C_{i, t}-H H M_{i, t} .
\end{aligned}
$$

\subsubsection{Big Firms (BFs) behaviour}

As stated earlier, BoE's APP decreases the cost of corporate bonds which triggers portfolio rebalancing. This induces BFs to replace part of their bank loans with corporate bonds and this section will specify the behavioural rule that BFs will use for this. The model assumes that BFs keep the size of physical capital and total debt unchanged, issue no new equity, and maintain a constant annual operating profit (i.e. profit before interest payments) to total assets ratio of $10 \%{ }^{21}$ In each period, a BF chooses the debt financing mixture to improve its net profit $\left(\pi_{i, t}\right)$ which is the difference between its operating profit $\left(O P P_{i, t}\right)$ and the cost of debt financing:

$$
\pi_{i, t}=B F O P P_{i, t}-r_{S, t} \cdot B F B d_{i, t}-r_{B F, t} . B F B L_{i, t} .
$$

Here, $r_{S, t}$ and $r_{B F, t}$ : the interest rates on bonds and bank loans, respectively, in period $t ; B F B d_{i, t}$ : the amount outstanding of $\mathrm{BF} i$ 's bonds in period $t$; $B F B L_{i, t}$ : the amount of bank loans owed by big firm $i$ in period $t$. The comparisons between bank borrowing and corporate bond issuance are based on the interest costs of the two sources. BFs will respond to decreases in bonds interest rate $\left(r_{S}\right)$, when it becomes equal to or smaller than the interest rate on bank borrowing $\left(r_{B F}\right)$, by issuing more bonds and using the proceeds to repay part of their bank loans. In other words, the debt mixture of BFs is restructured towards more corporate debt and less bank loans on average during the APP period. ${ }^{22}$

Note, the exogenous components of a BF balance sheet in any period $t$ to do with physical capital and gross operating profits of BFs will be anchored in empirical data. Eq. (12) states that the physical capital of the BF, $B F P h C_{i, t}$, remains unchanged from one period to the next, anchored by the initial distribution,

$$
B F P h C_{i, t}=B F P h C_{i, t-1} \text {. }
$$

Eq. (13) states the assumption that BF gross operating profits grow at empirically relevant rates in terms of its physical capital at time t:

$$
B F O P P_{i, t}=0.10 \times\left(B F P h C_{i, t-1}\right) .
$$

The $\mathrm{BF}$ cash holdings, $B F C_{i, t}$, is net of the interest payments on its corporate bonds and bank loans:

$$
B F C_{i, t}=B F C_{i, t-1}+B F O P P_{i, t}-r_{s, t} \cdot B F B d_{i, t-1}-r_{B F(t)} \cdot B F B L_{i, t-1} .
$$

The change in the debt composition of big firm $i$ in period $t, \triangle B F D C_{i, t}$, which is key to the portfolio balancing response to the lower yield on debt as a result of APP is given as follows in the behavioural rule (15). The status quo, with bank loans favoured over bond issuance, is maintained if, as stated in (15), the bond yield, $r_{S, t}$ is greater than interest on bank loans, $r_{B F, t}$. If the opposite is the case, BFs reduce their bank loans by upto $1.45 \% 23$ as follows:

$$
\begin{aligned}
& \triangle B F D C_{i, t}=\left\{\begin{array}{cl}
0 & \text { if } r_{S, t} \geq r_{B F, t} \\
\text { Random }[-0.014598 ; 0] & \text { if } r_{S, t}<r_{B F, t}
\end{array}\right\} \\
& B F B L_{i, t}=B F B L_{i, t-1}+\triangle B F D C_{i, t} \\
& B F B d_{i, t}=B F B d_{i, t-1}-\triangle B F D C_{i, t} .
\end{aligned}
$$

Hence, the net worth or equity of firms, $B F E_{i, t}$, is given as :

$$
B F E_{i, t}=B F P h C_{i, t}+B F C_{i, t}-B F B L_{i, t}-B F B d_{i, t} .
$$

\footnotetext{
${ }^{21}$ A $10 \%$ annual return on gross fixed capital stock for UK PNFCs is a good assumption. Data on annual Rates of Return for PNFCs given by ONS is estimated as the ratio of gross operating surplus (numerator) on gross fixed capital stock (denominator) and can be found at Table 1: https://www.ons. gov.uk/economy/nationalaccounts/uksectoraccounts/datasets/profitabilityofukcompaniesreferencetable. In 2009 this was $10.8 \%$ and in years pertinent to our analysis, it was around $11.6 \%$.

22 In a future edition of our ACE model, the extent to which funds raised by BFs from bonds are apportioned between repayment of bank loans and share repurchases will be modeled more explicitly. An explicit BF model that maximizes earnings per share (EPS) or net profits divided by the number of shares outstanding indicates that the return on capital, ROE, can be increased either by increasing net profits (lowering the debt cost in our analysis) or reducing the number of shares outstanding through share repurchases or buybacks. Given the complex issues involved here, see footnote 9 , a fuller model for big firm behavior that relates to maximizing shareholder value and on the debt/equity structure is beyond the scope of this ACE model.

${ }^{23}$ This is a historically relevant maximum fall in bank loans in a month for non-financial firms.
} 


\subsubsection{Bank lending behaviour}

As indicated, new bank lending for mortgages and to SMEs is driven by the portfolio rebalancing implemented by BFs in response to APP induced lower bond yields. We assume that banks do not issue new externally financed equity, and do not distribute any dividends and hence avail of new equity only from retained earnings or as relevant by changing the composition of its risk weighted assets. Banks aim to smooth their total stock of lending to HHs and non-financial firms and if they suffer reduced loan demand or increased loan repayments by BFs, they will attempt to compensate this by lending more to HHs for mortgages or to SMEs subject to capital constraints and perceived credit risks. To investigate the impact of regulatory capital adequacy requirements, the ACE model implements three different scenarios: no capital requirements, a Basel I simple capital requirements where equity capital is a fixed $8 \%$ proportion of total lending, and the more complex case where equity capital satisfies a ratio of risk weighted assets. The main behavioural difference that the introduction of Basel rules have brought about is an addition of risk weights to the banks' use of credit risk estimates on an ad hominem basis in the pre Basel regime. ${ }^{24}$ This involves an institutionalized implementation of a Basel compliant cost of capital measure. In summary : To track the impact of a QE-generated fall in demand for bank loans by BFs, banks change their portfolio of loans only to optimally accommodate the slack in demand in the total lending due to big firm substitution away from bank loans.

3.3.3.1. Scenario I: no capital requirements. In this scenario, banks do not have regulatory equity capital requirements. A bank grants mortgages and loans to SMEs to maximize its profit $\pi_{\mathrm{B}, \mathrm{t}}$, which is given by the following equation:

$$
\pi_{B, t}=\sum r_{i, t} \cdot L_{i, t}-\sum s_{i, t} \cdot\left(L_{i, t}\right) \cdot L_{i, t}
$$

Here $i=\{B F, H H, S M E\}$ : the agent class; $L_{i, t}$ : bank lending to agent of loan class $i$ at time $t ; r_{i, t}$ : interest rate on class $i$ loan at time $t ; s_{i, t}\left(L_{i, t}\right)$ : default risk cost of class i loan at time $t$ (i.e. the probability that an debtor of class $i$ loan defaults) which increases in the amount of lending to agents for class $i$ loans. We assume that the default risk costs are quadratic, $s_{i, t}\left(L_{i, t}\right)=L_{i, t}{ }^{2}$. As discussed earlier, banks proxy the default risk for each class of loans in terms of the non-performing loans at each time $t$ reported as write offs by UK banks for the loan class (see Appendix Fig. A1). In Eqs. (20) and (21), the optimal amounts of mortgages and loans to SMEs are determined by the difference between own interest rate and the interest rate on the other class of loans $\left(r_{H H}\right.$ and $r_{S M E}$ ), the ratio of the default risk of the other loan product to the total default risk of both loan products and the amount available for investment in the two types (i.e. the amount of total lending minus loans to $\mathrm{BFs}$ ). In other words, the second condition implies that banks increase bank loans to the one class, when the default risk on the other class increases, ceteris paribus. In order to keep the basic assumption of portfolio rebalancing for banks the same for all scenarios, we assume that banks aim to keep the amount of total lending, aggregated over the three categories of loans fixed, ${ }^{25}\left(L_{T o t}=L_{B F, t}+L_{H H, t}+L_{S M E, t}\right)$, and they only aim to reallocate optimally between HHs and SMEs of what remains the target loan total after adjusting for the wholly demand determined BF loan. We have the optimal amount of bank loans to households for mortgages, $L^{*} H H$, $t$, and SME loans, $L_{S M E, t}^{*}$, in (20) and (21), respectively: ${ }^{26}$

$$
\begin{gathered}
L_{H H, t}^{*}=\frac{\left(r_{H H, t}-r_{S M E, t}\right)+2 s_{S M E, t}\left(L_{T o t, t}-L_{B F, t}\right)}{2\left(s_{H H, t}+s_{S M E, t}\right)} \\
L_{S M E, t}^{*}=\frac{\left(r_{S M E, t}-r_{H H, t}\right)+2 s_{H H, t}\left(L_{T o t, t}-L_{B F, t}\right)}{2\left(s_{H H, t}+s_{S M E, t}\right)} .
\end{gathered}
$$

The first result here is that the banks operate without an explicit cost of capital, and even if there are larger default costs on loans to SMEs in (20), $s_{S M E, t}>s_{H H, t}$, this need not imply a natural bias toward mortgage loans as $r_{S M E}$ could be sufficiently greater than $r_{H H}$. However, Eqs. (20) and (21) indicate that a fall in loans to BFs, viz $\Delta L_{B F, t}<0$, driven by the lower bond yields, could induce banks to increase their supply of mortgages to HHs to a greater extent than loans to SMEs as the rates of default in the latter are typically higher than the former. As shown in Appendix 1, in 2009 Q1 the write offs on mortgages, which is used to proxy default risk, far exceeded that on SME loans. However, over the period of the start of APP to 2014, SME loan write offs increased while those for mortgages fell. Thus, when BF loans fall, whether or not banks increase SME loans more relative to household mortgages are governed by the respective comparative static conditions, which we denote as $\theta_{H H}$ and $\theta_{S M E}$, involving the relevant credit risk on the other loan:

$$
\begin{gathered}
\theta_{H H}=\frac{\partial L_{H H, t}}{\partial L_{B F, t}}=\frac{-s_{S M E, t}}{s_{H H, t}+s_{S M E, t}}<0, \\
\theta_{S M E}=\frac{\partial L_{S M E, t}}{\partial L_{B F, t}}=\frac{-s_{H H, t}}{s_{H H, t}+s_{S M E, t}}<0 .
\end{gathered}
$$

\footnotetext{
${ }^{24}$ For purposes of the ACE model, note that default risk is not assessed on the basis of individual loans, but on the class of loans for which empirical data is used.

25 This is subject to the capital adequacy conditions in Scenarios 2 and 3.

${ }^{26}$ Note given the assumptions made, the optimal lending equations in (20) and (21) are obtained from the profit function given as $\pi_{B . t}=r_{B F, t} L_{B F, t}+$ $r_{H H, t} L_{H H, t}+r_{S M E, t}\left(L_{T o t}-L_{B F, t}-L_{H H, t}\right)-s_{B F, t} L_{B F, t}^{2}-s_{H H, t} L_{H H, t}^{2}-s_{S M E, t}\left(L_{T o t, t}-L_{B F, t}-L_{H H, t}\right)^{2}$.
} 
Eqs. (22) and (23) imply that in Scenario 1, banks will increase both mortgages and SME loans in response to a slack created by the fall in BF loans, $\Delta L_{B F, t}<0$. Hence, each bank follows the following optimal rules when deciding the supply of new loans $\left(\Delta L_{H H, t}\right.$, and $\left.\Delta L_{S M E, t}\right)$ :

$$
\begin{aligned}
& \Delta L_{H H, t}=L_{H H, t}^{*}-L_{H H, t-1}+\theta_{H H}\left(\Delta L_{B F, t}\right), \\
& \Delta L_{S M E, t}=L_{S M E, t}^{*}-L_{S M E, t-1}+\theta_{S M E}\left(\Delta L_{B F, t}\right) .
\end{aligned}
$$

Eqs. (24) and (25) combine the optimal loan levels ( $L_{H H, t}^{*}$ and $\left.L_{S M E, t}^{*}\right)$ given in Eqs. (20) and (21) along with the impact of changes in BF demand for banks loans given in Eqs. (22) and (23).

3.3.3.2. Scenario II: simple capital requirements with no risk weights. To introduce the capital adequacy requirements, which state that at least a fraction $\gamma_{\text {Req }}$ of bank assets must be financed by equity, into the model, we follow AliagaDíaz et al. (2011) who state that if a bank has insufficient capital, it is subject to a cost that increases with the distance between the required capital to asset ratio and the actual one. Hence, the profit function of a bank in this case becomes:

$$
\pi_{B, t}=\sum\left(r_{i, t}-\delta\right) \cdot L_{i, t}-\sum s_{i, t} \cdot\left(L_{i, t}\right) \cdot L_{i, t}-\left(\mu \cdot \log \left(\frac{1}{\gamma_{t}}-\frac{1}{\gamma_{\text {req }}}\right)\right) \cdot L_{T o t, t} .
$$

Here $E$ : bank equity capital; $\delta=\sigma$. $\left(E_{t-1 / L_{T o t, t}}\right)$ : the cost of equity capital per $£ 1$ of total lending; $\sigma$ : the cost of equity capital estimated by using the Capital Asset Pricing Model (CAPM). ${ }^{27}$ In the last term in (26), which we denote by $\beta=$ $\mu \cdot \log \left(\frac{1}{\gamma}-\frac{1}{\gamma_{\text {req }}}\right)$, is the cost of having insufficient equity or the cost of noncompliance with the capital rules, and we can aggregate these costs $\alpha=\delta+\beta$, as they apply to total lending. Note $1 / \gamma$ is the leverage, which in the case of $8 \%$ capital ratio, is 12.5 . The main change in the banks' calculation of the profitability of loans as compared to the case of a simple regulatory capital requirement is the direct cost of equity, $\delta$, in (26) and also the penalty for deviations from the Basel approved leverage. The operational aspects of the binding capital constraints are governed by the $\mu$ which is an indicator function in Eq. (26) the values for which are defined as follows:

$$
\mu=\left\{\begin{array}{ll}
1 & \text { if } \gamma_{t}<0.08 \\
0 & \text { if } 0.10 \geq \gamma_{t} \geq 0.08 \\
0 & \text { if } \gamma_{t}>0.10
\end{array}\right\}
$$

In addition to the required equity to assets ratio $\left(\gamma_{\text {Req }}\right)$ of $8 \%$, an optional buffer of $2 \%$ is stipulated as in Repullo and Suarez (2013). The cost of noncompliance with the capital rules is assumed to be very high and can lead to bank failure. To avoid this high cost, banks try to keep equity to asset ratio very close to $10 \%$. In other words, each bank will change its total lending to ensure that equity to total lending ratio is between $8 \%$ and $10 \%$ (i.e. $8 \%<\gamma_{t}<10 \%$ ). This means that the upper bound of the feasible amount of total lending in any period $t\left(\overline{L_{T o t, t}}\right)$ which maintains the $10 \%$ equity to total lending is estimated:

$$
\overline{L_{T o t, t}}=10 E_{t-1}=\sum L_{i, t}, \text { if } 8 \%<\gamma_{t-1}<10 \% \text { and } L_{T o t, t} \#^{*}<\overline{L_{T o t, t}} \text { if } \gamma_{t-1}<8 \% \text {. }
$$

Thus, total lending has to be reduced from $\overline{L_{T o t, t}}$ if $\gamma_{t-1}<8 \%$ and we will denote this as $L_{T o t, t}{ }^{\#}$.

Accordingly, the profit function of the bank can be rewritten as follows:

$$
\pi_{B, t}=\sum\left(r_{i, t}-\delta\right) \cdot L_{i, t}-\sum s_{i, t} \cdot\left(L_{i, t}\right) \cdot L_{i, t}-\left(\mu \cdot \log \left(\frac{1}{\gamma_{t}}-\frac{1}{\gamma_{\text {req }}}\right)\right) . \overline{L_{T o t, t}} .
$$

As the total capital costs $\alpha=\delta+\beta$, apply equally to every $£ 1$ lent irrespective of the category of loan, the optimal amounts of mortgages and loans to SMEs in this Scenario 2 (highlighted with a double asterisks $* *$ ) correspond with the result in Scenario (1), with the only difference being the upper bound and (the capital constrained lower bound) of the total amount of lending being given by $\overline{L_{T o t}, t}$ in (28).

$$
\begin{aligned}
& L_{H H, t}^{* *}=\frac{\left(\left(r_{H H, t}-\alpha\right)-\left(r_{S M E, t}-\alpha\right)\right)+2 s_{S M E, t}\left(\overline{\bar{L}_{T O t, t}}-L_{B F, t}\right)}{2\left(s_{H H, t}+s_{S M E, t}\right)}=\frac{\left(r_{H H, t}-r_{S M E, t}\right)+2 s_{S M E, t}\left(\overline{L_{T o t, t}}-L_{B F, t}\right)}{2\left(s_{H H, t}+s_{S M E, t}\right)} \\
& L_{S M E, t}^{* *}=\frac{\left(\left(r_{S M E, t}-\alpha\right)-\left(r_{H H, t}-\alpha\right)\right)+2 s_{H H, t}\left(\overline{L_{T o t, t}}-L_{B F, t}\right)}{2\left(s_{H H, t}+s_{S M E, t}\right)}=\frac{\left(r_{S M E, t}-r_{H H, t}\right)+2 s_{H H, t}\left(\overline{L_{T o t, t}}-L_{B F, t}\right)}{2\left(s_{H H, t}+s_{S M E, t}\right)} .
\end{aligned}
$$

Eqs. (31) \& (32) indicate that a fall in loans to BFs induces banks to increase its supply of mortgages and loans to SMEs using the comparative static conditions $\theta_{H H}$ and $\theta_{S M E}$ EqS. (22) \& (23) as in Scenario I. The behavioural rules a bank follows

\footnotetext{
${ }^{27}$ For example, see Rizzi (2013).
} 
when deciding the supply of new loans to be granted $\left(\Delta L_{H H, t}\right.$, and $\left.\Delta L_{S M E, t}\right)$ depend on the value of its equity to total lending in the previous period $\left(\gamma_{t-1}\right)$. In this context, we distinguish between the three possible cases shown below.

Case. $A: M=0$ and $8 \%<\gamma_{t-1}<10 \%$ :

In this case a bank will maintain its total lending unchanged, and will change the size of mortgages and loans to SMEs only if there was a change in the stock of its loans to BFs:

$$
\begin{aligned}
& \Delta L_{H H, t}=\theta_{H H} \cdot\left(\Delta L_{B F, t}\right), \\
& \Delta L_{S M E, t}=\theta_{S M E} \cdot\left(\Delta L_{B F, t}\right) .
\end{aligned}
$$

Case. B: $M=0$ and $\gamma_{t-1}>10 \%$ :

In this case, the bank has excess lending capacity that it can use to grant more mortgages and loans to SMEs. Consequently, analogous to Scenario I, the supply of new loans to be granted will be as follows:

$$
\begin{aligned}
& \Delta L_{H H, t}=L_{H H, t}^{* *}-L_{H H, t-1}+\theta_{H H}\left(\Delta L_{B F, t}\right), \\
& \Delta L_{S M E, t}=L_{S M E, t}^{* *}-L_{S M E, t-1}+\theta_{S M E}\left(\Delta L_{B F, t}\right) .
\end{aligned}
$$

Case. C: $M=1$ (or $\left.\gamma_{t-1}<8 \%\right)$ :

A bank facing this situation is over-lending and will decrease its total lending to $L_{\text {Tot, }}{ }^{\#}$ as noted in (28) to decrease the cost of noncompliance with the capital adequacy rules. The behavioural rules will follow (35) and (36) with $L_{T o t, t}^{\#}$ providing the capital complaint upper bound for total loans given there.

3.3.3.3. Scenario III: complex fractional capital requirements with risk weights . Like Scenario II, banks are required to finance a fraction of their asset using equity capital. However, the capital requirements in Scenario III assign different risk weights to different types of assets following Basel II/III and the capital requirements take the form of an equity to risk weighted asset ratio specified in below in (37). The profit function of a bank in this case takes the following formula, which is analogous to the non-risk weighted leverage ratio constraints on banks in (29), with the respective risk weighted equivalent terms for cost of capital $\delta_{i}^{\#}$ and the (reciprocal of) regulatory ratio, $\gamma_{R e q}^{\#}$, and actual capital ratios, $\gamma^{\#}$ :

$$
\pi_{B, t}=\sum\left(r_{i, t}-\delta_{i}^{\#}\right) \cdot L_{i, t}-\sum s_{i, t} \cdot\left(L_{i, t}\right) \cdot L_{i, t}-\left(\mu^{\prime} \cdot \log \left(\frac{1}{\gamma_{i}^{\#}}-\frac{1}{\gamma_{r e q}^{\#}}\right)\right) \cdot L_{T o t, t} \cdot
$$

Here, actual leverage as given by risk weighted asset to equity is:

$$
\frac{1}{\gamma^{\#}}=\frac{1}{\frac{E_{t-1}}{w_{B F} \cdot L_{B F, t}+w_{H H} \cdot L_{H H, t}+w_{S M E} \cdot L_{S M E, t}}}=\frac{w_{B F} \cdot L_{B F, t}+w_{H H} \cdot L_{H H, t}+w_{S M E} \cdot L_{S M E, t}}{E_{t-1}} \text {. }
$$

We denote, $w_{B F}<w_{H H}<w_{S M E}$ : risk weights for loans to BFs, mortgages, and loans to SMEs, respectively; $E$ : bank equity capital; $\delta_{i}^{\#}=\sigma^{\#} \cdot w_{i} \cdot \frac{E_{t-1}}{L_{\text {Tot } t-1}}$ : the cost of equity capital per $£ 1$ of lending to class $i$ agents; $\sigma^{\#}$ : the cost of equity capital estimated by using the Capital Asset Pricing Model (CAPM); $\gamma_{R e q}^{\#}$ : the required equity to risk weighted assets ratio; $\gamma^{\# \text { : }}$ the actual equity to risk weighted assets ratio; $\mu$ : is a positive parameter.

As in Scenario II, banks attempt to maintain equity to risk weighted assets ratio very close to $10 \%$. Therefore, the behaviour of a bank in any period $t$ depends on the value of its equity to risk weighted assets $\left(\gamma_{t}^{\#}\right)$. Again, each bank will determine its total lending to ensure that $8 \%<\gamma_{t}^{\#}<10 \%$, which we will denote generically as $\overline{L_{\text {Tot }, t} \#}$ to cover the range of values this can take.

The first order conditions with respect to mortgages and loans to SMEs show that, in addition to the relative yields and credit risk, the total amount available for mortgages and loans to SMEs, the risk weights and bank equity have a significant impact on the optimal allocation between the two types of loans:

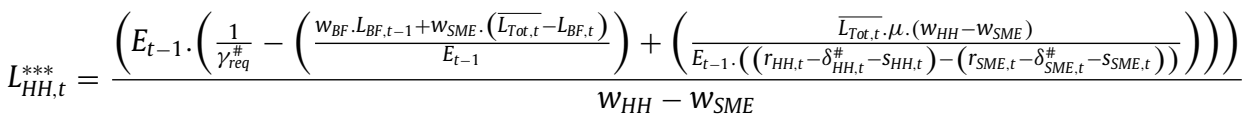

$$
\begin{aligned}
& L_{S M E, t}^{* * *}=\frac{\left(E_{t-1} \cdot\left(\frac{1}{\gamma_{r e q}^{*}}-\left(\frac{w_{B F} \cdot L_{B F, t-1}+w_{H H} \cdot\left(\overline{L_{T o t, t}}-L_{B F, t}\right)}{E_{t-1}}\right)+\left(\frac{\overline{L_{T o t . t}} \cdot \mu \cdot\left(w_{S M E}-w_{H H}\right)}{E_{t-1} \cdot\left(\left(r_{S M E, t}-\delta_{S M E, t}^{H}-S_{S M E, t}\right)-\left(r_{H H, t}-\delta_{H H, t}^{H}-S_{H H, t}\right)\right)}\right)\right)\right)}{w_{S M E}-w_{H H}}
\end{aligned}
$$

In Eqs. (38) and (39) for the optimal loan allocations for mortgages and SMES, the first term in numerator gives the extent to which the required risk weighted leverage defined in (37) deviates from the actual risk weighted leverage in terms of lending at $\mathrm{t}-1$ for bank loans and the risk weighted allocation to the other loan class in terms of the slack in total 
loans after exogenous BF loan determination at $t$. The second term in the numerators of (38) and (39) are operative only if the indicator function in (27) $\mu=1$, viz. the bank is not capital constrained by the Basel II capital adequacy requirement. The difference in rates of return between the two competing loan classes adjusted for their respective cost of capital and default risks feature in the denominator of the second terms in (38) and (39).

Eqs. (40) \& (41) indicate that a fall in loans to BFs $\left(L_{B F}\right)$ will induce banks to categorically increase mortgages, and to decrease loans to SMEs as per the following comparative statics:

$$
\begin{aligned}
& \rho_{H H}^{* * *}=\frac{\partial L_{H H}}{\partial L_{B F}}=-\frac{\left(w_{B F}-w_{S M E}\right)}{w_{H H}-w_{S M E}}<0 \\
& \rho_{S M E}^{* * *}=\frac{\partial L_{S M E}}{\partial L_{B F}}=-\frac{\left(w_{B F}-w_{H H}\right)}{w_{S M E}-w_{H H}}>0 .
\end{aligned}
$$

Thus, unlike Scenarios I and II, in Scenario III, as seen in Eq. (41), as the comparative static term $\rho_{\text {SME }}$ multiples the term representing the slack in total bank lending that is brought about by the portfolio rebalancing by BFs away from bank loans, with $\Delta L_{B F, t}<0$, this will not lead to any increase in SME lending as the differences in the administratively set risk weights given in (41) that are biased against SMEs, will militate against this. Eq. (41) gives the, ceteris paribus, rule of thumb that as loans to big firms are reduced, $\Delta L_{B F, t}<0$, given the size of regulatory weights below, this yields a $60 \%$ reduction to SME loans for every $£ 1$ reduction in loans to big firms. In contrast, the risk weights favouring mortgages in (40), result in 1.6 times expansion of mortgage loans for every $£ 1$ reduction in loans to big firms, subject to capital constraints.

In fact, in Case C (see Scenario II) when banks are under capitalized with $\boldsymbol{\gamma}_{\mathbf{t}-\mathbf{1}} \#<\mathbf{8 \%}$, SMEs will now lose loan share as follows:

$$
\Delta L_{S M E, t}^{* * *}=-\frac{1}{w_{S M E}} \cdot\left(R W A_{t-1}-\frac{1}{0.08} E_{t-1}\right)+\rho_{S M E}^{* * *} \cdot\left(\Delta L_{B F, t}\right)<0 .
$$

This is due to the first term in brackets in (42) being positive by definition of $\boldsymbol{\gamma}_{\mathbf{t}-\mathbf{1}} \#<\mathbf{8 \%}{ }^{28}$ and the second term is also negative from (41) when $\Delta L_{B F, t}<0$. This is the negative double whammy that SMEs face in being frozen out of loans due to the bias in the Basel II weights against them, especially, when a bank is capital constrained.

The risk weights used in the model for different loan types are taken from BIPRU 3.4 Risk weights under the standardised approach to credit risk available Financial Conduct Authority (FCA). The value of these risk weights are as follows with $\mathrm{w}_{\mathrm{BF}}$ being the weights on corporate loans, $\mathrm{w}_{\mathrm{HH}}$ those on mortgages and $\mathrm{w}_{\mathrm{SME}}$ the $100 \%$ weights on loans to SMEs :

\begin{tabular}{|ccc|}
\hline$W_{B F}$ & $W_{H H}$ & $W_{S M E}$ \\
\hline $20 \%$ & $50 \%$ & $100 \%$ \\
\hline
\end{tabular}

Source: BIPRU 3.4 Risk weights under the standardised approach to credit risk; Financial Conduct Authority (FCA); Available at: https://www.handbook.fca.org.uk/handbook/BIPRU/3/4.html\#D591.

\subsubsection{SMEs behaviour}

Like BFs, SMEs have a constant but lower annual operating profit to total assets ratio of 5\%, and keep the size of physical capital fixed over the simulation period. The main characteristic of SMEs is that they cannot control their debt financing (like BFs) since the single source of this financing is bank loans. The latter depend solely on banks' willingness to grant loans or extend/renew current credit facilities to these firms. Additionally, the model assumes that SMEs have unlimited demand for debt financing and that they cannot raise further external equity financing during the simulation period. As shown above in Scenario III, the Basel II/III risk weight, which are biased against SMEs loans imply that they cannot enjoy any increase in loans especially in the period of APP when BFs start to replace bank loans with bonds. This situation is more drastic when banks suffer capital inadequacy as shown in (42). Consequently, the components of a SME balance sheet in a given period t are as follows, respectively, for the physical capital of SME, $S M E P h C_{i, t}$, and SME operating profits, $S M E O P P_{i, t}$, which is set in (44) at $5 \%$ of physical capital ${ }^{29}$ and $\operatorname{SMEC}_{i, t}$, the cash holdings of SME $i$ in period $t$ :

$$
\begin{aligned}
& \text { SMEPhC }_{i, t}=\text { SMEPhC }_{i, t-1} \\
& \text { SMEOPP }_{i, t}=0.05 \times\left(S M E P h C_{i, t-1}+S_{M E C} C_{i, t-1}\right) .
\end{aligned}
$$

\footnotetext{
${ }^{28}$ Note as $\gamma_{t-1} \#=\frac{E_{t-1}}{R W A_{t-1}}<0.08$, rewriting this, we see that $\frac{E_{t-1}}{0.08}<R W A_{t-1}$.

${ }^{29}$ In contrast to the $10 \%$ return on gross fixed capital for big firm PNFCs, see footnote 21 , we are justified in halving this return for SMEs as only about $60 \%$ of SMEs post a profit during market downturns as in the APP period, see https://www.statista.com/statistics/291377/small-and-mediumenterprises-sme-wholesale-retail-profitability-uk/.
} 


\begin{tabular}{|c|c|c|}
\hline Rate & $\begin{array}{l}\text { Col } 1 \text { : Interest rate - } \\
\text { Initial Value (Average Value 2009-Q1 } 2015 \\
\text { using ) }\end{array}$ & $\begin{array}{l}\text { Col 2: Default Rates /Credit Risk } \\
\text { Premia - Initial Value (Average } \\
\text { Value 2009-Q1 2015) } \\
\text { Denoted by } S_{i} t \text { : default risk cost of class i loans }\end{array}$ \\
\hline Policy rate: risk free rate $\left(r_{\mathrm{RF}}\right)^{1}$ & $0.5 \%$ & N.A \\
\hline Government gilts rate $\left(r_{G}\right)$ & $3.35 \%\left(r_{G}^{\#}=2.79 \%\right)^{2}$ & N.A \\
\hline Interest rate on mortgages $\left(\mathrm{r}_{\mathrm{HH}}\right)^{3}$ & $6.06 \%^{3}\left(r_{R F}+5.9 \%=6.4 \%\right)$ & $12.6 \%(5.9 \%)^{5}$ \\
\hline Interest rate on BFs loans $\left(\mathrm{r}_{\mathrm{BF}}\right)^{4}$ & $5.3 \%{ }^{4}\left(r_{R F}+7.1 \%=7.6 \%\right)$ & $3.6 \%(7.1 \%)^{5}$ \\
\hline Interest rate on BFs bond debt $\left(r_{s}\right)$ & $6 \%\left(r_{G} \# 2+2.23 \%{ }^{7}=5.02 \%\right)$ & $9.89 \%^{6}\left(2.23 \%{ }^{7}\right)$ \\
\hline Interest rate on SMEs loans ( $\left.r_{S M E}\right)$ & $8.8 \%\left(r_{R F}+10.3 \%=10.8 \%\right)$ & $8.3 \%(10.3 \%)$ \\
\hline
\end{tabular}

Fig. 5. Initial Values (Q4 2008/Q1 2009) and Average Values (In Brackets) of Interest Rates and Default/Credit Risk Premia (Annual).

1 BoE's policy rate. (Source: Bank of England (http://www.bankofengland.co.uk)); ${ }^{2}$ Yield (\%) on medium term 10-year gilts in December 2008 with average yield over the period denoted by $\mathrm{r}_{\mathrm{G}}{ }^{*}=2.79 \%$ (Source: https://dmo.gov.uk/data/ExportReport?reportCode=D4H); ${ }^{3}$ Interest rate on mortgages: Sterling weighted average interest rate on loans secured on dwellings (CFMB168) in BoE interactive website, Feb 2009; ${ }^{4}$ Interest rate on BF loans: Sterling weighted average interest rate on PNFC loans (CFMB162) in BoE interactive website Feb 2009..$^{5}$ Data on write offs from BoE website, see Appendix Fig. A.1. 6,7 Speculative grade global bond default rate for 2009 : S\&P Global Ratings Table 1 with the value in brackets being the average for the period excluding initial date $^{30}$.

In (45), SMEC $i, t$, the cash holdings of SME $i$ in period $t$ is given as the cash holdings in t-1, its operating profits in t, less the interest on SME bank loans at $\mathrm{t}-1, S M E B L_{i, t-1}$, and the bank determined change in the amount of bank loans granted to SME $i$ in period $t, \triangle S M E B L_{i, t}$ :

$$
\begin{aligned}
& S M E C_{i, t}=S M E C_{i, t-1}+S M E O P P_{i, t}-r_{S M E, t} S M E B L_{i, t-1}+\triangle S M E B L_{i, t}, \\
& S M E B L_{i, t}=\triangle S M E B L_{i, t-1}+\triangle S M E B L_{i, t}, \\
& S M E E_{i, t}=S M E P h C_{i, t}+S M E C_{i, t}-S M E B L_{i, t} .
\end{aligned}
$$

In Eq. (47), the net worth or equity of the $S M E, S M E E_{i, t}$, is given as the value of its physical capital, the SME cash deposits less the value of its bank loans.

\section{Initial ACE model conditions and simulation results}

\subsection{ACE model initial Conditions, policy rates and risk premia}

Section 3.1 outlined the data driven agent characteristics for the UK economy and the Appendix has given additional details and the data sources for this. Fig. A3 in the Appendix gives the initial conditions and the balance sheet data for the agents as set out in Sections 3.2-3.4. The only remaining variables that need to be discussed are the price variables. The policy rates and lowering of bond yields triggered by APP are for the most part considered to exogenous to agents' behaviour.

The ACE model includes 6 different interest rates and 3 proxies for credit risk/default rates on the 3 classes of bank loans (needed for the variables $\left.s_{i, t}\left(L_{i, t}\right), i=\{B F, H H, S M E\}\right)$ and the default rate on corporate bonds. The initial values and the average values over the period from 2009 - Q1 2015 (given in brackets) are presented in Fig. 5 above. The average values in brackets give a better indication of how the impact of QE changes, in particular, the gilt yields and how the different loan categories fair in terms of default risk over the period. First, the risk-free rate $\left(r_{R F}\right)$ and gilts rate are set to the actual levels of BoE policy rate $(0.5 \%)$ and 10 -year gilts rate $(3.35 \%)$ just before the launch of APP in 2009 with the mortgage rates and the corporate bond rates, respectively, tracking this over time. It should be noted that while the policy interest rate remained at 0.5\%, the 10 year gilt yields fell to under 2\% in May 2012, remained there till May 2013 and never rising above 3\% thereafter. Likewise, despite the very high bond default rates in 2009, Fig. 5 column (2), with the bond default rates falling over this period along with the fall in gilt yields bringing on average the cost of bond issuance to around $5 \%$. The impetus for issuance of bonds follows as the interest rate of bank loans to big firms increases to over 7.6\%. With Fig. 5 showing that the initial interest rates on PNFC bank loans was lower than the cost of corporate bond issuance underscores the fact that in the immediate pre APP period of 2009, corporate bonds represented only 32.7\% of nonfinancial corporations' total debt.

Further, premia on different types of bank loans are given to reflect the credit risk or default probability of the loans and the cost of capital for banks. The credit risks denoted by $s_{i, t}\left(L_{i, t}\right), \mathrm{i}=i=\{B F, H H, S M E\}$ are proxied by the UK bank write off

30 This can be found at https://www.spratings.com/documents/20184/774196/2016+Annual+Global+Corporate+Default+Study+And+Rating+Transitions.pdf/ 2ddcf9dd-3b82-4151-9dab-8e3fc70a7035. 
a

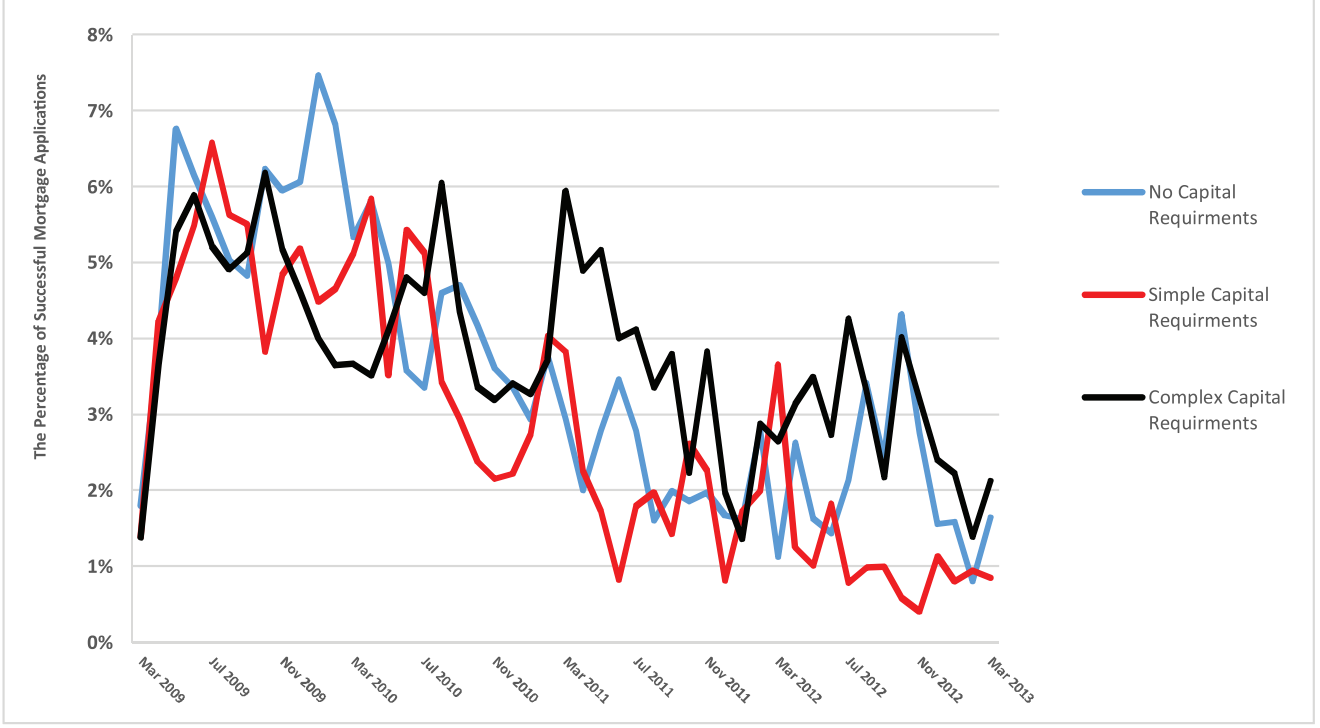

\begin{tabular}{|l|c|c|c|c|}
\hline & $\begin{array}{c}\text { Sample Average } \\
\text { Mortgage } \\
\text { Approvals }\end{array}$ & Std Deviation & $\begin{array}{c}\text { Lower Bound at } \\
95 \% \text { confidence } \\
\text { level }\end{array}$ & $\begin{array}{c}\text { Upper Bound at } \\
95 \% \text { confidence } \\
\text { level }\end{array}$ \\
\hline Scenario 1 & $0.035053^{*}$ & 0.045601 & 0.030308 & 0.039798 \\
\hline Scenario 2 & $0.028589^{*}$ & 0.046082 & 0.023794 & 0.033384 \\
\hline Scenario 3 & $0.037547^{*}$ & 0.045793 & 0.032782 & 0.042312 \\
\hline
\end{tabular}

Fig. 6. a The proportion of successful mortgage applications (Monthly) - Average of 50 Simulations for each Scenario. b Monthly mortgage approval rates (Averaged over 50 simulations for each of the Scenarios).

Notes: Scenario 1 : No Capital Requirements; Scenario 2: Simple 8\%-10\% Basel I capital requirements; Scenario 3: Complex Basel II/III risk weighted capital requirements

* Statistically significant P-values at 95\% confidence level.

rates for each class of loans. As seen in Appendix Fig. A1, the initial values of default risk as proxied by the quarterly write off rates is $0.31 \%$ for mortgages (annual rate $12.6 \%$ ), $0.2 .6 \%$ for SMEs (annual rate $10.3 \%$ ) and $0.18 \%$ (annual rate $3.6 \%$ ) for BFs. However, on average over time, SMEs have a higher write off rate and as shown in Fig. 5. Hence, in Fig. 5, loans to SMEs are given the highest initial interest rate of $8.8 \%$, followed by $6.06 \%$ for mortgages and $5.3 \%$ for loans to BFs.

\subsection{Simulation results}

As stated earlier, the model in this paper covers a period of 50 months from the start of APP in 2009 and it involves the micro simulations of the interaction between different agents and the responses of these agents to the developments in debt markets. At any given month $t$, asset purchases under APP lead to an exogenous fall in gilts yield which is reflected in the yield of corporate bonds through the portfolio rebalancing effect. BFs start to change their debt financing structure when the cost of bonds becomes lower than bank loans cost. Meanwhile, each household receives its income, finances its consumption, pays its mortgage instalment, and accumulates the rest into its cash holdings.

The first set of results that are pertinent are the monthly rates of mortgage approvals under the 3 bank capital regime scenarios given in Fig. 6a. These results are averaged over 50 simulations for each scenario and for ease of perusal the outputs of the 3 scenarios are given in one graph, Fig. 6a, with Fig. 6 b giving the upper and lower bounds for the sample mean values at $95 \%$ confidence level. These are found to be statistically significant at 5\%. The charts on mortgage approvals for the 3 scenarios with 95\% confidence bands are given in Appendix Fig. A4. These results hold the key to the systematic bias in bank lending in favour of mortgages in the Basel II/III risk weighted regime of Scenario 3.

While all 3 scenarios show a downward trend in mortgage approvals, Scenario 3 dominates in terms of the sample mean of $3.75 \%$ of monthly mortgage approval rates as shown in Fig. 6b. Following the time series in Fig. 6a, this is the case especially after 2010 . Scenario 1 comes a close second with approval rates at $3.5 \%$, driven as it is by the relative credit risks given in the estimates proxied by bank write offs on mortgages which fall considerably by the end of 2009 while SME write offs increased (see Appendix Fig. A1). Scenario 2 shows a considerable lower average in terms of monthly mortgage approval rates of $2.85 \%$ as it has the least scope to respond to capital adequacy constraints with no risk weights that favour a switch to mortgages. 


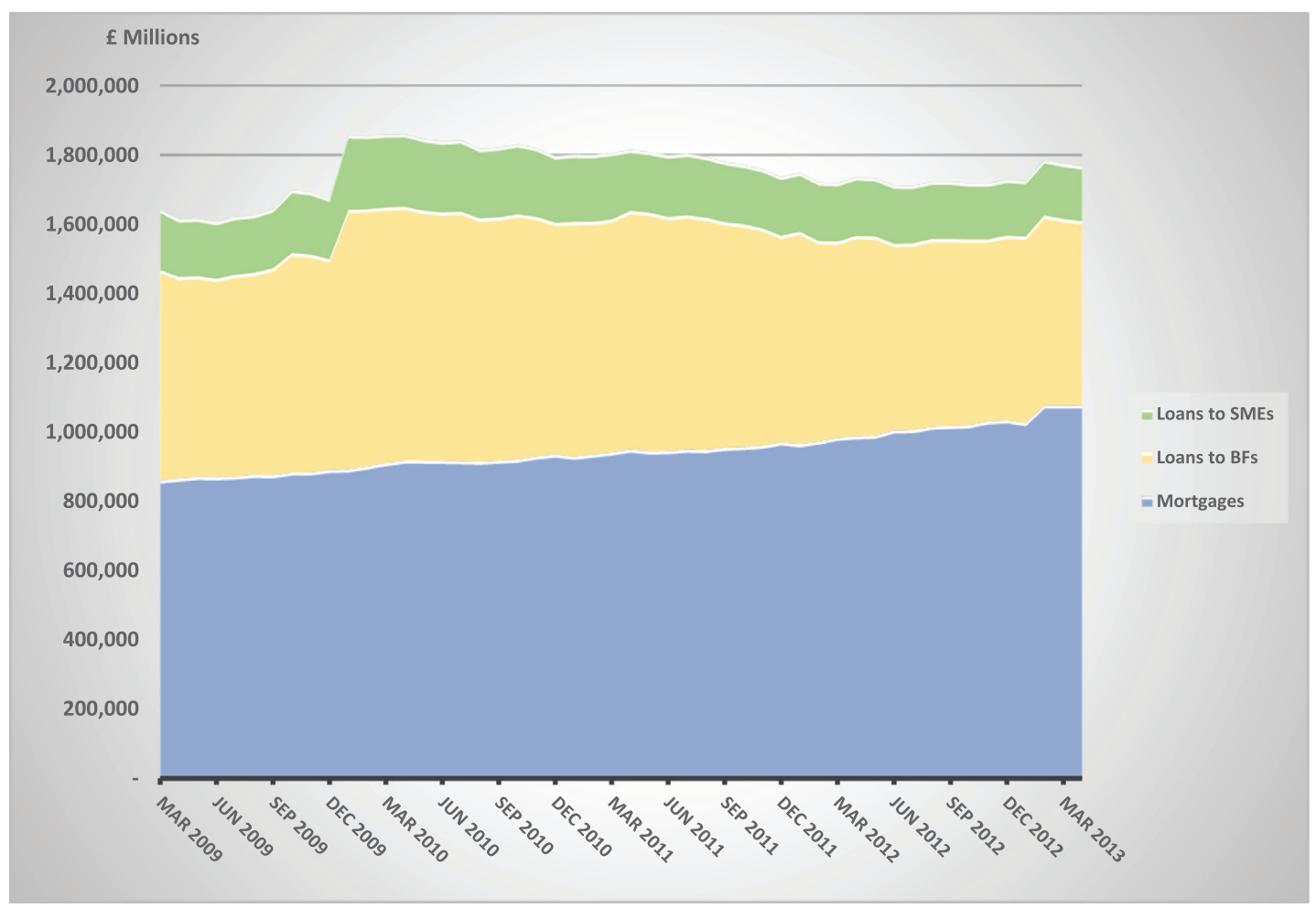

Fig. 7. Actual UK Bank lending aggregates.

Source: Bank of England's Bankstats (http://www.bankofengland.co.uk/statistics/Pages/bankstats/default.aspx).

We will now analyse the results in terms of the aggregate lending, with the breakdown for mortgages, loans to BFs, and loans to SMEs for the 3 scenarios given in Figs. 8, 10 and 11 respectively. To make them comparable to actual data given in Fig. 7, the amounts of mortgages, loans to BFs, and loans to SMEs have been rescaled up using the proportions between the actual and the hypothetical numbers of the agents in the ACE model. The main exogenous operative factor is that BFs do not change their debt structure during the first 20 periods till the APP impact on bond yields bite and the cost of security debt is still bigger than the cost of bank borrowing. The actual data in Fig. 7 shows how the total bank loans for the classes of loans under consideration starts at about $£ 1.6$ trillion in 2009, achieves a relative peak in March 2010 at $£ 1.81$ trillion, which, after a severe crunch then trends downwards to $£ 1.75$ trillion in March 2013, marking a fall of about £60bn from the peak. The breakdown shows that only mortgages grew from $£ 0.860$ trillion in March 2010 to about $£ 1$ trillion in 2013, about a £140bn increase. Other loans types, respectively, fell over this period from $£ 0.60$ trillion to $£ 0.45$ trillion for BFs (£150bn fall) and from $£ 0.20$ trillion to $£ 0.15$ trillion for SMEs (£50bn fall).

The main results here is as expected, only the extant Basel II/III Scenario 3, Fig. 8, corresponds closely with the actual data and produces the result that only the mortgage lending picks up somewhat while bank lending to the real economy falls. Thus, the simulated results given in Fig. 8 show a very close correspondence with the actual data though the 2013 March total lending is somewhat smaller at $£ 1.55$ trillion as opposed to about $£ 1.72$ trillion in actual data in Fig. 7. As the key assumption in our framework is that the impact of QE manifests first in the portfolio rebalancing behaviour by BFs in favour of bond issuance, the following Fig. 9 summarizes this result with the follow through implications of the assumption that a BF one for one substitutes away from bank loans as it changes its bond to total debt ratio. This then causes the rebalancing in bank portfolios in terms of mortgages and SME loans under the 3 scenarios. Fig. 9 shows how the ACE simulation based on the BF behavioural rule in Section 3.3.2 Eq. (15) for bond issuance results in larger absolute increases of bond issuance of $£ 87.92$ billion over the period from the start of APP (March 2009) to April 2013 compared to the $\$ 68.48$ billion actual increase on PNFC bonds based on data in Fig. 2. However, the simulated results imply a less aggressive increase of $9.9 \%$ in the BF bonds to total debt ratio than the actual increase of $15.7 \%$ over the relevant period. This is due to the assumption in Eq. (16) that simulated bank loans to BFs starting at about 1604 billion are reduced onefor-one with the funds generated by bond issues. Corresponding to the comparative static Eq. (41) rule of thumb of a 60\% of the fall in loans to big firms, $\Delta L_{B F, t}<0$, in Scenario 3, SMEs suffer a fall in loans from $£ 0.20$ trillion in 2009 to $£ 0.147$ trillion in 2013, about $£ 52.1$ billion. This is somewhat larger than the actual fall of $£ 50$ bn in SME loans in this period. Finally, in the case of Scenario 3, from Figs. 8 and 9 we see that simulated mortgage lending starts at about $£ 0.81$ trillion in 2009, shows the similar peak as with the actual data in July 2010 of about $£ 1.0$ trillion, falls somewhat to recover to over $£ 1.1$ trillion in May-September of 2012 and then falls to $£ 0.92$ trillion in March 2013. This implies an overall cumulative increase of $£ 110$ bn of mortgage loans in the simulated case. As in the actual data, the increase in mortgage lending fails to overcome 


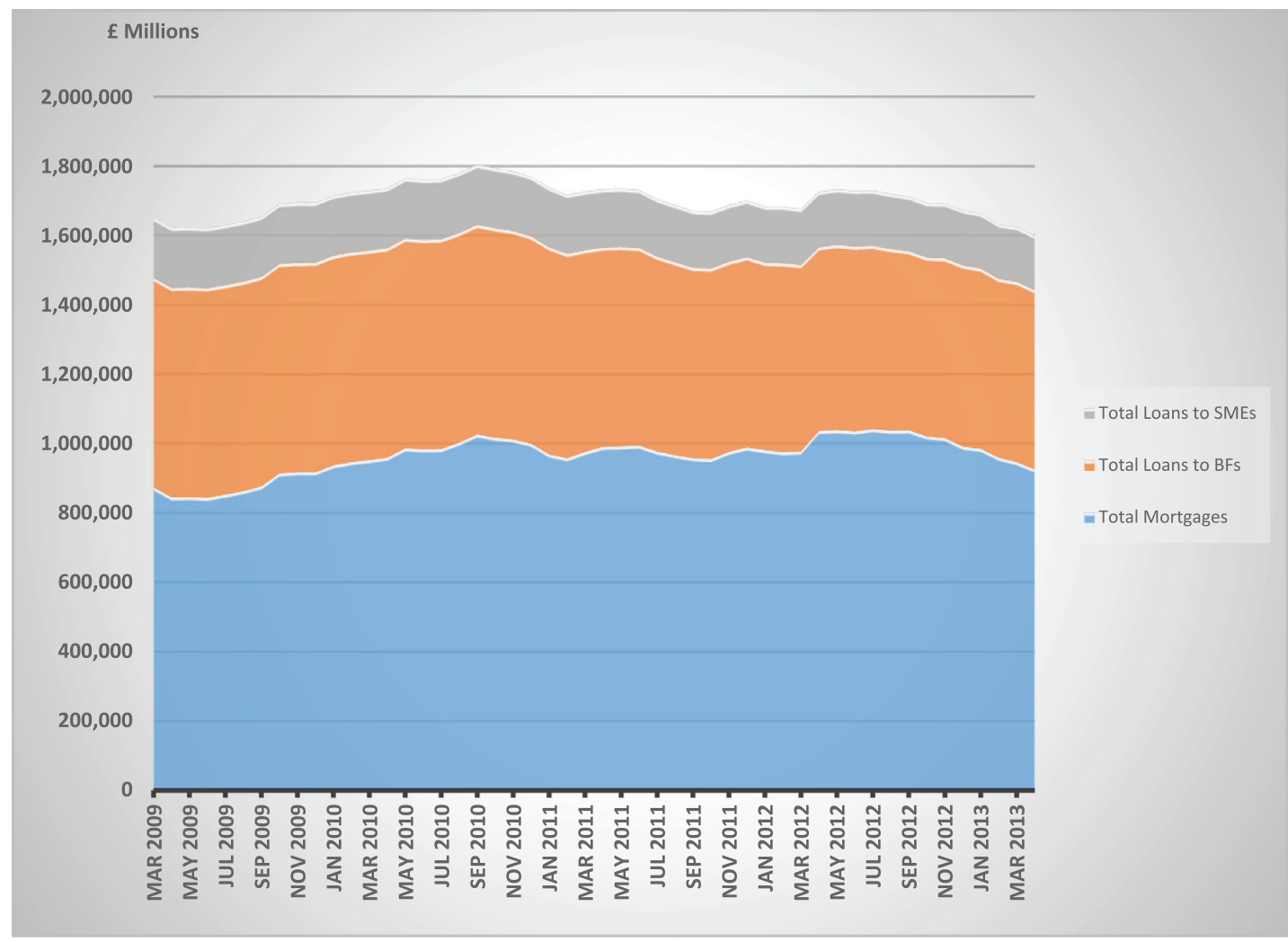

Fig. 8. Simulated bank lending aggregates fmillions (complex capital requirements; risk weights) Scenario 3 (see Section 3.3.3.3).

\begin{tabular}{|c|c|c|c|c|c|c|c|c|c|c|}
\hline & \multicolumn{2}{|c|}{$\begin{array}{l}\text { BF Bond Issuance ( } \mathrm{f} \\
\text { bns) }\end{array}$} & \multicolumn{2}{|c|}{$\begin{array}{l}\text { BF Bonds to total debt } \\
\text { (bank loans + bonds) \% }\end{array}$} & \multicolumn{3}{|c|}{$\begin{array}{l}\text { Cumulative changes }{ }^{2} \text { in } \\
\text { mortgages (simulated) fbns }\end{array}$} & \multicolumn{3}{|c|}{$\begin{array}{l}\text { Cumulative change in loans } \\
\text { to SMEs (simulated) fbns }\end{array}$} \\
\hline & Actual $^{1}$ & Simulated & Actual & Simulated & $\begin{array}{l}\text { Scen1 } \\
\text { Initial } \\
\text { £770bn }\end{array}$ & $\begin{array}{l}\text { Scen2 } \\
\text { Initial } \\
\text { £770bn }\end{array}$ & $\begin{array}{l}\text { Scen3 } \\
\text { Initial } \\
\text { £810bn }\end{array}$ & $\begin{array}{l}\text { Scen1 } \\
\text { Initial } \\
£ 150 \text { bn }\end{array}$ & $\begin{array}{l}\text { Scen2 } \\
\text { Initial } \\
\text { £150bn }\end{array}$ & $\begin{array}{l}\text { Scen3 } \\
\text { Initial } \\
\text { £200bn }\end{array}$ \\
\hline $\begin{array}{l}\text { Start of APP } \\
\text { (Mar 2009) }\end{array}$ & f344.26 & f293.47 & $32.7 \%$ & $32.7 \%$ & 0 & 0 & 0 & 0 & 0 & 0 \\
\hline Dec 2011 & f388.25 & $f 348.85$ & $44.1 \%$ & $38.9 \%$ & $£ 41.3$ & $£ 23.5$ & $f 115$ & $£ 0.5$ & $£ 1.7$ & $-£ 9.8$ \\
\hline June 2012 & $£ 396.57$ & $£ 363.47$ & $45.2 \%$ & $40.5 \%$ & $f 4.9$ & f91.5 & f45.8 & $£ 3.7$ & $£ 4.8$ & $-f 12.4$ \\
\hline Dec 2012 & $£ 406.16$ & $£ 375.5$ & $46.7 \%$ & $41.8 \%$ & f10.8 & $-£ 34.5$ & $-£ 43.71$ & $£ 4.2$ & $£ 4.1$ & $-f 14.3$ \\
\hline $\begin{array}{l}\text { End of APP } \\
\text { (Apr 2013) }\end{array}$ & $£ 412.74$ & f381.39 & $48.4 \%$ & $42.5 \%$ & $-f 5.6$ & $£ 13.7$ & $f 51.9$ & $£ 5.7$ & f6.2 & $-£ 15.6$ \\
\hline $\begin{array}{l}\text { Change } \\
\text { (start to } \\
\text { end) }\end{array}$ & f67 & $£ 87.92^{3}$ & $15.7 \%$ & $9.9 \%$ & f51.4 & $£ 94.2$ & $£ 110$ & f14.1 & $f 16.8$ & $-£ 52.1$ \\
\hline
\end{tabular}

Fig. 9. Summary of key simulated results on big firm bond issuance, mortgage loans and loans to SMEs Under the 3 Scenarios (Scen 1-3).

${ }^{1}$ Actual data for Big Firm Bond Issuance is given from the same source in Fig. 2 (Data code CPMB29M from the BOE interactive website); ${ }^{2}$ Cumulated between dates shown; ${ }^{3}$ Note given the assumptions in Section 3.3.2 Eq. (15), and the initial value of loans to big firms of about $£ 604$ bn, this category of loans fall at the same rate as bond issuance. Hence in the given period, the ACE model will register the same $£ 88$ bn reduction in loans to big firms which corresponds to the value of bonds issued (simulated).

the fall in loans to big firms and to SMEs. Recall that banks loans to big firms in the ACE model falls by the same amount as the size of bond issuance of about $£ 87.92 \mathrm{bn}$. Hence, these results support our hypothesis as to how banks will respond to the conditions of APP when operating under Basel II/III risk weights.

Fig. 9 shows a systematic bias against SME lending in Scenario 3, which operates in an iron clad way resulting in loan reductions throughout this period when compared to SME loans under the other 2 scenarios, which continue to be positive. It is important to note that while our result is not inconsistent with the studies of Thakor (1996), and Heid, Porath and Stolz (2004) results, in that banks suffering from capital inadequacy will look to improve their capital status by shifting out of high risk weighted loans/assets, the ACE model here builds a more detailed set conditions of APP that triggered a series of events which reduced both BF loans and loans to SMEs. SMEs suffered disproportionately only due to their unfavorable BaseI 


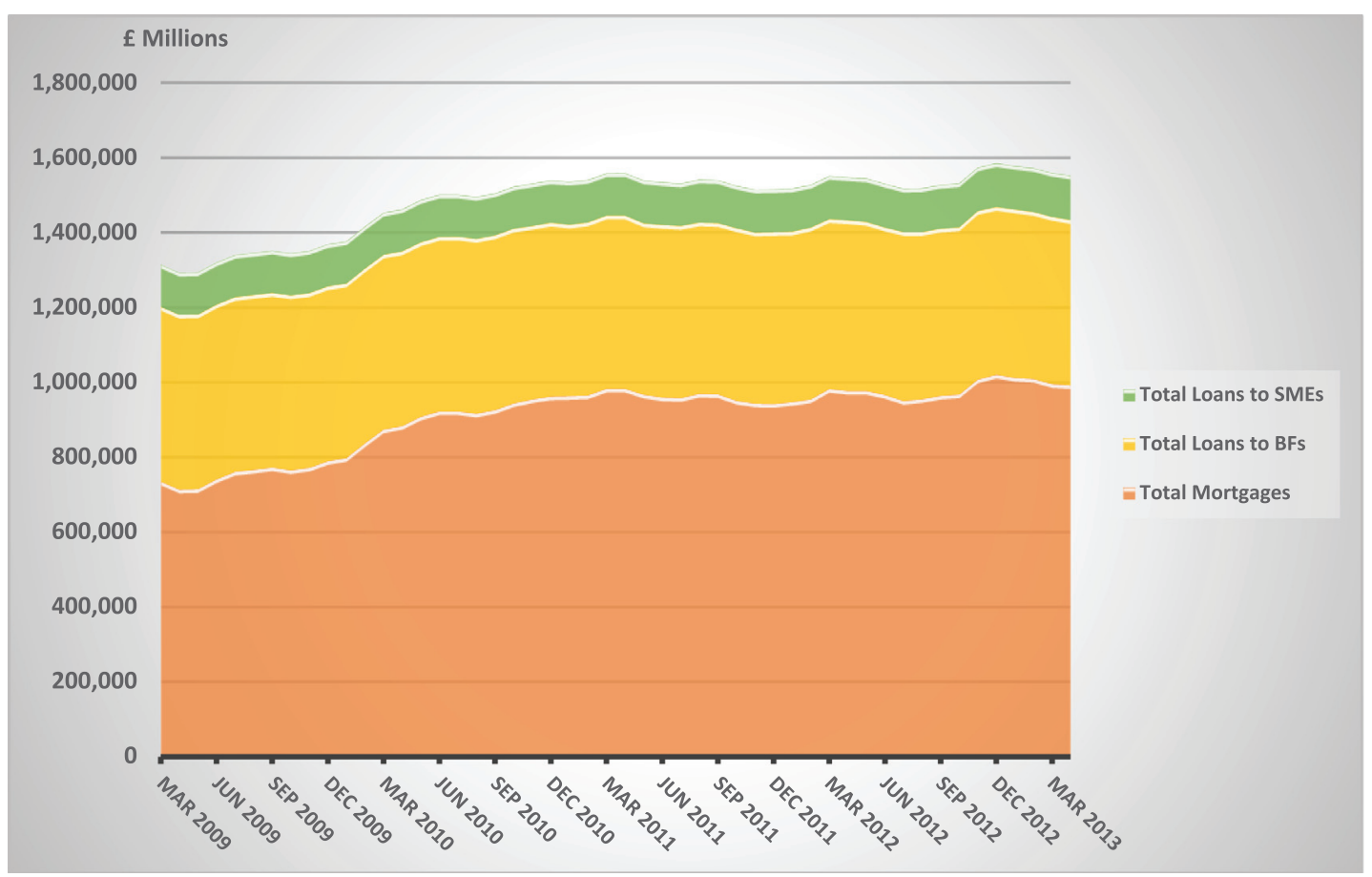

Fig. 10. Simulated bank lending aggregates (simple capital requirements; no risk weights). Scenario 2 (see Section 3.3.3.2). Average of 50 simulation runs.

I/III risk weights. As the results from the other 2 scenarios show, there was nothing in the economic credit risk conditions surrounding SMEs that this should have been the case.

Thus, in contrast to the simulated outputs from Scenario 3, the other 2 scenarios do not show a fall in lending to SMEs. In the case of Scenario 2, Fig. 10, SMEs enjoy about the same level of loans around $£ 0.1$ Trillion and in fact this increases to about $£ 0.12$ Trillion in 2013 March. It is expected that as Basel I unweighted 8\% capital implies identical leverage of 12.5 for all asset classes, this could reduce total lending compared with Scenario 3. Hence, total lending in 2009 was £1.3 trillion below the actual data of $£ 1.6$ Trillion, while in March 2013, Scenario 2 shows about the same level of total lending as in the case of the simulated Scenario 3 at $£ 1.5$ trillion. But what is interesting in Scenario 2 is that with a lack of bias, the growth in mortgage lending from $£ 0.78$ trillion in March 2009 to around $£ 0.95$ trillion in March 2013, a cumulatively increase of £94bn (see, Fig. 10), is not at the expense of loans to SMEs. Loans to SMEs hold firm and also increase about $£ 16.8 \mathrm{bn}$.

Finally, there is a counterintuitive result regarding Scenario 1, Fig. 11, which shows the lowest amount of total lending at about $£ 1.1$ trillion in 2009 and $£ 1.2$ trillion in 2013 March. The idea that the absence of an explicit regulatory capital rule need not lead to excessive lending runs contrary to what is often assumed. Indeed, as long as the banks are guided by the optimal rule based on the relative credit risk proxies given in Section 3.2.3.1, there is clearly no threat of excessive lending. Also, the lack of bias against SME lending means that this category of lending remains stable at about £0.15 Trillion throughout the conditions of APP in Scenario 1 and in fact increases by about $£ 14$ bn over this period, Fig. 11. Mortgage loans also increase from £770bn in March 2009 to about £820bn in March 2013.

\subsection{Model validation}

Several validation methods have been used to validate simulated models in engineering in computer sciences. For instance, Sargent (2013) outlines 17 techniques that can be used to validate simulation models. These techniques use logical reasoning, quantitative methods, or visual representation to verify the soundness of simulated models. One of these techniques, historical data (or empirical) validation, is recommended by Windrum et al. (2007) to assess models in the context of ACME. In their history-friendly approach, a good model is one that can generate several stylized facts observed in the actual data. To validate the model of this paper, this section examines the degree to which simulated lending aggregates represent actual lending aggregates. To do that, two sets of regressions are run for the Scenario 3 simulated results. The $\mathrm{R}^{2}$ results, given in Figs. 12 and 13 of Scenario 3, which corresponds with the regime in situ, clearly outperformed the regressions results of the other 2 scenarios (not reported).

In the first test set, each of the time series of simulated and actual lending aggregates is regressed on time $(t)$. This can shed light on similarities on time trends between the actual and simulated data given by the slope coefficients (same signs and/or statistical significance). The model specification for this test is $\boldsymbol{L}_{i t}=\alpha+\beta t+\epsilon_{t}$, where $\mathbf{L}$ are loans to BFs, SMEs, mortgages and total lending for the simulated and actual time series. 


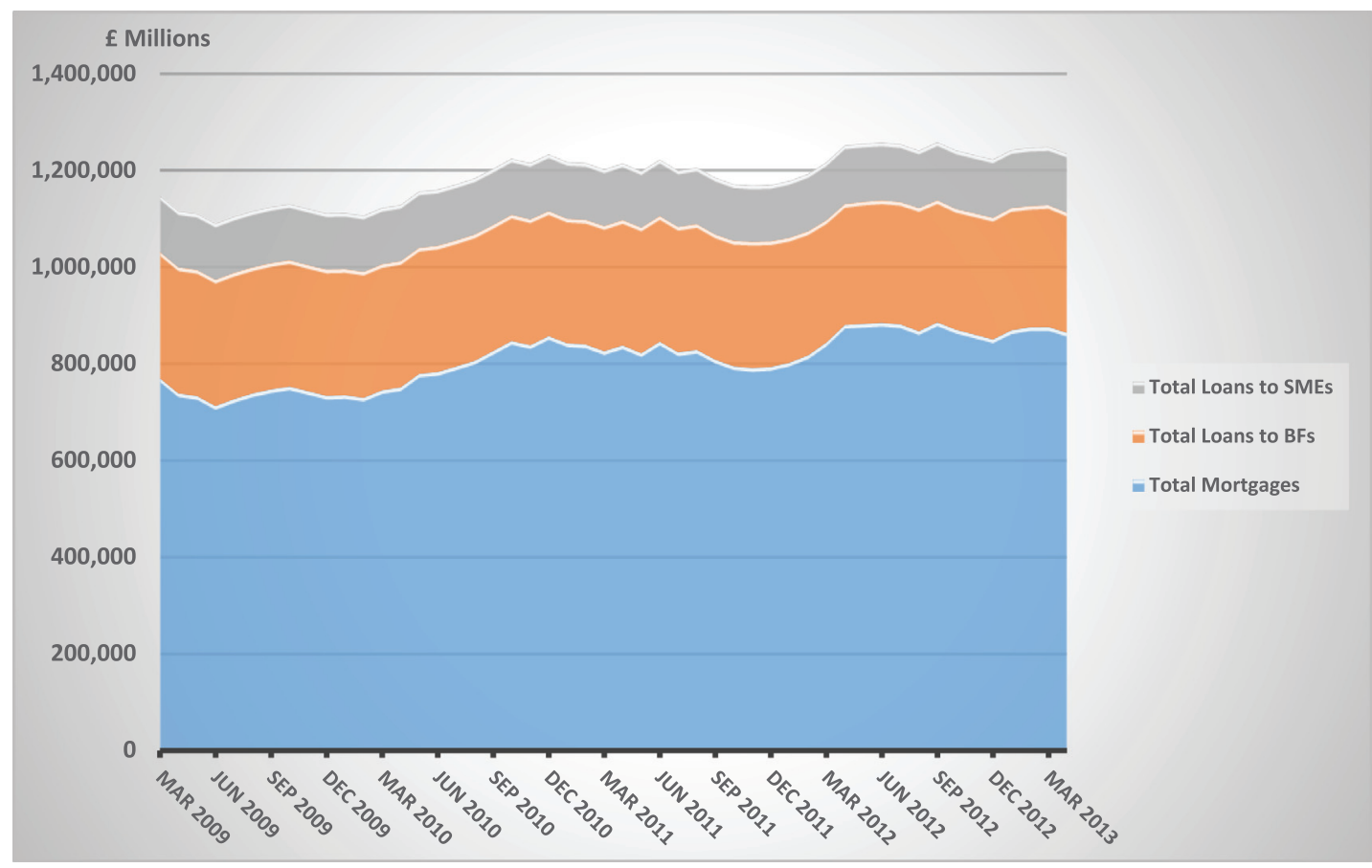

Fig. 11. Simulated bank lending aggregates (no capital requirements) scenario 1 (see Section 3.3.3.1). Average of 50 simulation runs.

\begin{tabular}{|c|c|c|c|c|}
\hline Variable & Coefficient on time & Standard Error & p value & $\mathbf{R}^{2}$ \\
\hline Simulated BFs Loans & $1.64 \times 10^{10}$ & $1.51 \times 10^{9}$ & 0.00 & 0.7059 \\
\hline Actual BFs Loans & $1.80 \times 10^{10}$ & $1.68 \times 10^{9}$ & 0.00 & 0.7008 \\
\hline Simulated SMEs Loans & $4.87 \times 10^{9}$ & $4.26 \times 10^{8}$ & 0.00 & 0.7269 \\
\hline Actual SMEs Loans & $5.18 \times 10^{9}$ & $4.71 \times 10^{8}$ & 0.00 & 0.7122 \\
\hline Simulated Mortgages & $2.93 \times 10^{10}$ & $2.17 \times 10^{9}$ & 0.00 & 0.7879 \\
\hline Actual Mortgages & $2.91 \times 10^{10}$ & $2.04 \times 10^{9}$ & 0.00 & 0.8063 \\
\hline Simulated Total lending & $5.06 \times 10^{10}$ & $4.11 \times 10^{9}$ & 0.00 & 0.7557 \\
\hline Actual Total lending & $5.23 \times 10^{10}$ & $4.17 \times 10^{9}$ & 0.00 & 0.7574 \\
\hline
\end{tabular}

Fig. 12. Summary of the simulated (Scenario3) and actual bank lending aggregates regressions on time.

\begin{tabular}{|c|c|c|c|c|}
\hline Variable & $\begin{array}{c}\text { Coefficient on the } \\
\text { Simulated Variable }\end{array}$ & Standard Error & p value & $\mathbf{R}^{\mathbf{2}}$ \\
\hline Actual BFs Loans & 1.27151 & 0.1787335 & 0.00 & 0.5132 \\
\hline Actual SMEs Loans & 1.70887 & 0.2548637 & 0.00 & 0.4836 \\
\hline Actual Mortgages & 0.6392122 & 0.1185209 & 0.00 & 0.3773 \\
\hline Actual Total lending & 0.9728365 & 0.1510779 & 0.00 & 0.4635 \\
\hline
\end{tabular}

Fig. 13. Summary of the regression of actual on simulated bank lending aggregates.

Fig. 12 shows very high similarities between simulated and actual coefficients on time for each loan class. The coefficients on the simulated variables are statistically significant at a high $99 \%$ confidence level.

The regressions in the second group investigate the correlation between simulated and actual data by regressing each actual time series on the corresponding simulated one. The model specification for this test is $\boldsymbol{L}^{\text {Actual }}{ }_{i t}=\alpha+\beta \mathbf{L}^{\text {simulated }}{ }_{i t}+\epsilon_{t}$, where $\mathbf{L}$ are loans to BFs, SMEs, mortgages and total lending. 
The coefficients on the simulated variables are statistically significant at a high $99 \%$ confidence level while $\mathrm{R}^{2}$ values in Fig. 13 reveal robust correlations between the actual and simulated bank lending aggregates. Similarly, the comparison between the results of the regressions of each of the actual bank lending aggregates with the corresponding results for simulated aggregates indicate that the simulated data is a very good representation of the actual data. But as discussed in the outputs from the simulations, the response of agents to a regulatory system in place is far from satisfactory as it leads to a systematic bias against loans to SMEs.

\section{Conclusion}

A standard textbook model of bank lending starts with the premise that banks' primary objective is to lend to nonfinancial firms. We set up a data driven agent based model (ABM) of the UK bank lending to households for mortgages and to big firms and SMEs that reflects the reality on the ground that this is far from the case. In the context of $Q E$ and APP launched by UK authorities in 2009, increasing bank lending was one of the main goals. Yet, ONS sectoral financial accounts data shows that although bank lending to households for mortgages has been expanding since 2009, total bank lending witnessed a noticeable drop driven by a decrease in lending to businesses, especially to SMEs. We explicitly take the reduced bond yields in the course of APP for triggering a portfolio rebalancing by big firms in the direction of bond issuance and a substitution away from bank loans as the main factor behind the demand side fall in bank loans from big non-financial firms. We have shown that a data rich ACE model of the UK banking system, which is equipped with the Basel II/ III regulatory bank capital constraints, is needed to demonstrate how the slack caused in the bank loan portfolios by big firm substitution in favour of bonds post APP, helped expand UK loans for mortgages at the expense of loans to SMEs. As noted by Goodhart and Ashworth (2012), ${ }^{31}$ this overall contraction in UK bank lending, especially to SMEs, while mentioned in the many papers on the impact of APP that use event studies and econometric models, they have failed to give a cogent explanation.

In the spirit of Stiglitz (2011) and Jones (2000), we focus on the incentives and constraints posed by the Basel capital adequacy rules on the UK banking system. The ACE model was developed to investigate the conditions created by APP and QE in the UK primarily on bank supply side responses for lending to households for mortgages and to SMEs, which unlike big firms do not have access to the bond market. We have raised the important question whether regulatory capital requirements should penalize sectors like SMEs when clearly the credit risk conditions do not warrant this. Indeed, the complex Basel II/III risk weighted framework has been implicated for causing perverse incentives and destabilizing capital arbitrage that exploits the risk weights both in the run up to 2007 GFC, Markose et al. (2012) and in the case of the Eurozone crisis, Acharya and Steffan (2015).

Following the recent BoE agent based model of the UK mortgage market, Baptista et al. (2016), our data driven ACE model anchors the mortgage eligibility conditions for UK households in empirical data on their income distribution, extant home owner status and net worth after mortgage indebtedness. Likewise, the relevant financial balance sheet data of other agent classes are used as initial conditions. An important empirical scale factor is used to determine the proportions of the agents in the different classes to simulate the UK economy and to produce simulation outputs that are similar in value to actual macro-economic data. As we saw this has worked. Likewise, to focus on how the key bank lending decisions operate, we recommend that ACE models should embrace the embedding of an endogenous section within a framework of the wider economic data which is fed exogenously to the agents as they make their decisions at each time step within the simulator. This is a new ingredient to ACE modelling that can produce quantitative outputs that are of similar magnitudes as actual variables and produce finely tuned institutionally rich simulations for policy analysis. Finally, we think that there is some urgency to develop an extension to the extant ACE model to give more details for the behaviour of US and UK companies, which have been given the impetus by APP to issue bonds. These funds have been used to pay back bank loans and to pursue what many regard to be an excessive strategy of share buy backs that can contribute to stock market bubbles, corporate indebtedness and slow growth.

\section{Acknowledgements}

We are grateful for comments from the editor and two anonymous referees that have improved the paper. We also thank participants for their inputs at workshops where this paper has been presented: 4th European Conference on Banking and the Economy 12 October 2016; BoE One Bank Seminars 28-06-2017; Money, Macro and Finance Group 49th Annual Conference 5-7 September 2017. Mahmoud Fatouh has received feedback from Economics Masters and PhD students at the University of Essex where he gives annual guest lectures on this agent based model since 2016.

\footnotetext{
31 Goodhart and Ashworth (2012) have used colourful language as follows: "QE has not worked via a major expansion of bank assets/liabilities is simply taken as a fact of life, and a conspiracy of silence has fallen over any discussion/analysis of why this happened. [...] And why "these routes have failed to facilitate an expansion of bank credit expansion, notably to small and medium-sized enterprises (SMEs)" (Ibid).
} 


\section{Appendix A. Empirical evidence on the UK economy}

The UK economy data around the launch of APP in 2009 is used as empirical base for the ACE model. The Appendix includes relevant data that was used in the ACE model for the nonfinancial sectors (households and nonfinancial businesses) and banks in the UK that has not been discussed in Section 3.

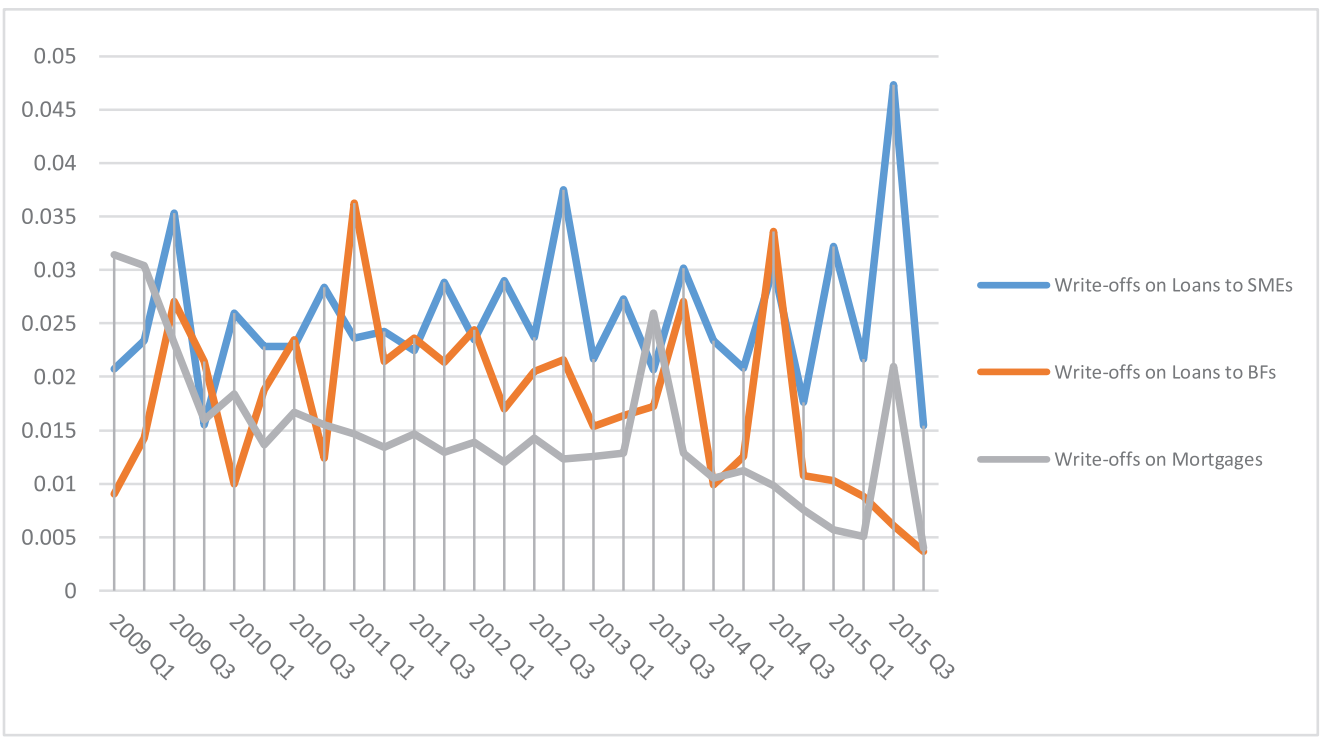

Fig. A1. Quarterly loan write-offs (\%) by UK banks by loan type.

Note: The probability of default is proxied by the ratio of loan write-offs to the total amount of loans for each loan type. The amounts of loan write-offs and total mortgages and business loans to BFs and SMEs are available from BoE. ${ }^{32}$ Total PNFCs (i.e. PFs + SMEs): loans (LPMB4VR), write offs (RPQTFHB). SMEs: loans (RPMZ8YH), write offs (RPQTFHK).

Source: Bank of England (http://www.bankofengland.co.uk/boeapps/iadb/newintermed.asp).

\begin{tabular}{|c|c|c|}
\hline \multicolumn{1}{|c|}{ Bank } & Date & Equity to Total Assets Ratio \\
\hline HSBC & $31 / 12 / 2008$ & $2.05 \%$ \\
\hline Barclays & $31 / 12 / 2008$ & $2.12 \%$ \\
\hline Royal Bank of Scotland & $31 / 12 / 2008$ & $2.65 \%$ \\
\hline Lloyds & $31 / 12 / 2008$ & $2.22 \%$ \\
\hline Standard Chartered & $31 / 12 / 2008$ & $4.84 \%$ \\
\hline NatWest & $31 / 12 / 2008$ & $4.19 \%$ \\
\hline Santander UK & $31 / 12 / 2013$ & $4.66 \%$ \\
\hline Nationwide & $31 / 12 / 2008$ & $3.36 \%$ \\
\hline The Co-operative Bank & $31 / 12 / 2008$ & $5.27 \%$ \\
\hline Clydesdale and Yorkshire Bank & $31 / 12 / 2008$ & $4.85 \%$ \\
\hline
\end{tabular}

Fig. A2. Top 10 UK banks equity to total assets ratios.

Source: Bankscope Database available at (http://www.bvdinfo.com). 


\begin{tabular}{|c|c|c|c|c|c|c|c|}
\hline Variable & \multicolumn{6}{|c|}{ Value/Distribution } & Assumptions/Empirical facts \\
\hline \multicolumn{8}{|l|}{ Households } \\
\hline Number of households & \multicolumn{6}{|c|}{100,000} & Scaled down from $21,464,730$ \\
\hline \multirow{2}{*}{ Number of houses per household } & Number & 0 & 1 & 2 & 3 & 4 & Only $64 \%$ of UK households own at least \\
\hline & Probability & 0.36 & 0.16 & 0.16 & 0.16 & 0.16 & one property \\
\hline House price & \multicolumn{6}{|c|}{$f 149,400$} & Average house price in 2009 Q1. \\
\hline Household housing wealth & \multicolumn{6}{|c|}{ Number of Houses $x$ House price } & \\
\hline Household cash & \multicolumn{6}{|c|}{ Uniformly distributed between $£ 5,000$ and $£ 50,000$} & \\
\hline Household mortgage liability & \multicolumn{6}{|c|}{ Uniformly distributed between $\mathrm{f0}$ and $£ 70,965$} & $\begin{array}{l}\text { - } 52 \% \text { of the homeowners have mortgages } \\
\text { - HHs average mortgage liability in } 2009 \text { Q1 } \\
\text { was } £ 49,070\end{array}$ \\
\hline Household equity & \multicolumn{6}{|c|}{$\begin{array}{l}\text { Household housing wealth }+ \text { household cash - household } \\
\text { mortgage liability }\end{array}$} & \\
\hline Household income & \multicolumn{6}{|c|}{ Log-normally distributed } & $\begin{array}{l}\text { The distribution is estimated using the } \\
\text { monthly equivalents of IFS's parameters of } \\
\text { the weekly income distribution (in } 2009 \text { Q1) }\end{array}$ \\
\hline Household preferred bank & \multicolumn{6}{|c|}{ Randomly selected } & \\
\hline \multicolumn{8}{|l|}{ Big Firms } \\
\hline Number of big firms & \multicolumn{6}{|c|}{24} & Scaled down from 4,405 \\
\hline Big firm Physical capital & \multicolumn{6}{|c|}{ Uniformly distributed between $f 5$ million and $£ 100$ billion } & \\
\hline Big firm cash & \multicolumn{6}{|c|}{ (0.1283/0.8717) x physical capital } & $\begin{array}{l}\text { cash represented } 12.83 \% \text { of nonfinancial } \\
\text { firms' total assets in } 2009 \text { Q1 }\end{array}$ \\
\hline Big firm debt to total assets ratio & \multicolumn{6}{|c|}{$51.66 \%$} & $\begin{array}{l}\text { NFCs debt to total assets ratio in } 2009 \text { Q1 } \\
\text { was } 51.66 \%\end{array}$ \\
\hline Big firm loans & \multicolumn{6}{|c|}{$34.77 \% \times$ (physical capital + cash) } & $\begin{array}{l}\text { Loans represented } 67.3 \% \text { of NFCs total debt } \\
\text { in } 2009 \text { Q1. }(67.3 \% \times 51.66 \%=34.77 \%)\end{array}$ \\
\hline Big firm bonds & \multicolumn{6}{|c|}{$16.89 \% \times$ (physical capital + cash) } & $\begin{array}{l}\text { Bonds represented } 32.7 \% \text { of NFCs total debt } \\
\text { in } 2009 \text { Q1. }(32.7 \% \times 51.66 \%=16.89 \%)\end{array}$ \\
\hline Big firm equity & \multicolumn{6}{|c|}{$\begin{array}{l}\text { Big firm physical capital + big firm cash - big firm loans - big } \\
\text { firms bonds }\end{array}$} & \\
\hline Big firm preferred bank & \multicolumn{6}{|c|}{ Randomly selected } & \\
\hline \multicolumn{8}{|l|}{ Small and medium enterprises } \\
\hline Number of SMEs & \multicolumn{6}{|c|}{22,900} & Scaled down from $4,918,915$ \\
\hline SME Physical capital & \multicolumn{6}{|c|}{ Uniformly distributed between $£ 50,000$ and $£ 1$ million } & \\
\hline SME cash & \multicolumn{6}{|c|}{ (0.1283/0.8717) x physical capital } & $\begin{array}{l}\text { cash represented } 12.83 \% \text { of nonfinancial } \\
\text { firms' total assets in } 2009 \text { Q1 }\end{array}$ \\
\hline SME debt to total assets ratio & \multicolumn{6}{|c|}{$40 \%$} & SMEs are can only avail of bank loans \\
\hline SME loans & \multicolumn{6}{|c|}{$40 \% \times$ (physical capital + cash) } & \\
\hline SME equity & \multicolumn{6}{|c|}{ SME physical capital + SME cash - SME loans } & \\
\hline SME preferred bank & & & ndomly & lected & & & \\
\hline Banks & & & & & & & \\
\hline Number of banks & & & 10 & & & & \\
\hline Bank total mortgages & Sum of & mortgag & of $\mathrm{HHs}$ & hat deal & ith the b & & See above household mortgage liability \\
\hline Bank loans to big firms & Sum o & loans to & ig firms & lat deal & th the br & & See above big firm loans \\
\hline Bank loans to SMEs & Sum & of loans & SMES tI & $t$ deal $w$ & the ban & & See above SME loans \\
\hline Bank deposits & Sum of cas & h of hou & $\begin{array}{l}\text { holds, } \mathrm{b} \\
\text { with the }\end{array}$ & firms ar & SMEs th & deal & See above for details \\
\hline Bank equity & Mortgages & + loans $t$ & big firm & + loans $t$ & SMEs - c & osits & See above for details \\
\hline
\end{tabular}

Fig. A3. The initial values/distributions of the model's variables. 


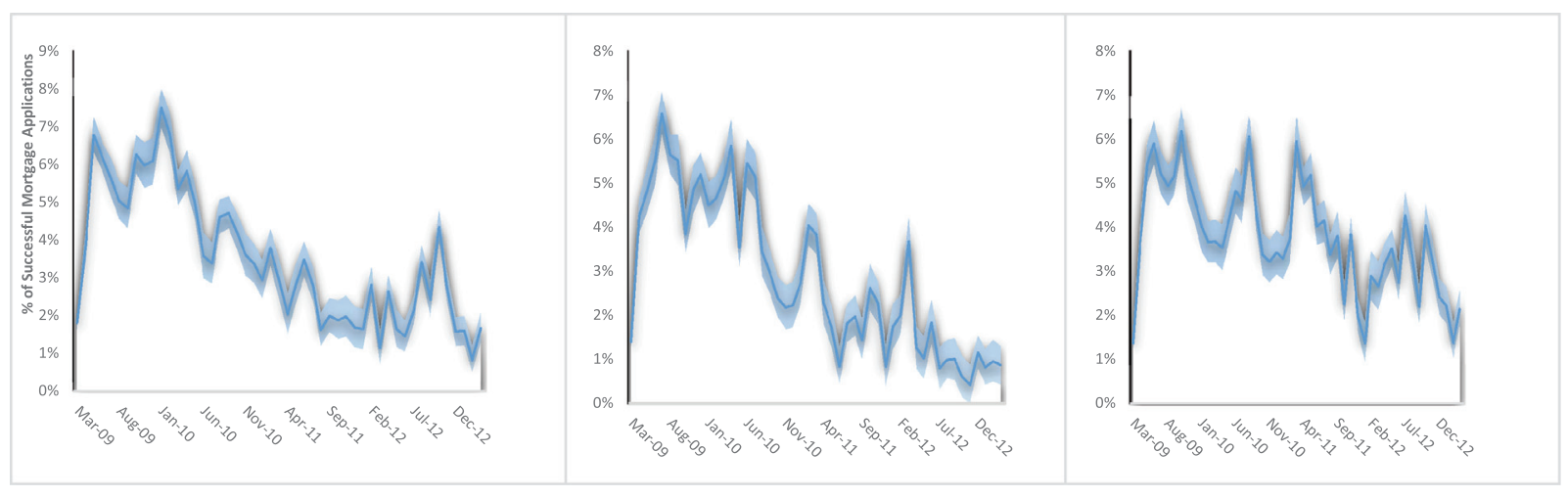

Fig. A4. 95\% Confidence interval bands for mortgage approval rates given in Fig. $6 \mathrm{~b}$.

a. Scenario 1 b. Scenario 2 c. Scenario 3.

Note: Shaded area represents $95 \%$ confidence interval based on 50 simulations.

\section{References}

Acharya, V.V., Steffen, S., 2015. The "greatest" carry trade ever? Understanding eurozone bank risks. J. Financ. Econ. 115 (2), $215-236$.

Akerlof, G.A., 2002. Behavioral macroeconomics and macroeconomic behavior. Am. Econ. Rev. 92 (3), 411-433.

Aliaga-Díaz, R. M. Olivero, and A. Powell (2011); The macroeconomic effects of anti-cyclical bank capital requirements. School of Economics, Working Paper Series, 2016-16, LeBow College of Business, Drexel University.

Angelini, P., Clerc, L., Cúrdia, V., Gambacorta, L., Gerali, A., Locarno, Vlček, J., 2015. Basel III: long-term impact on economic performance and fluctuations. Manchester Sch. 83 (2), 217-251.

Arcand, J.-L., Berkes, E., Panizza, U., 2015. Too Much Finance? J. Econ. Growth 20 (2), 105-148.

Arthur, W.B., 2006. Chapter 32 Out-of-Equilibrium Economics and Agent-Based Modeling. Handbook of Computational Economics.

Baddeley-Chappell, A., 2013. Will the extended funding for lending scheme mean more of the same for mortgage rates? Available at http://www. nationwide-intermediary.co.uk/blog/2013-07-26 accessed 02 November 2014.

Baptista, R., Farmer, J.D., Hinterschweiger, M., Low, K., Tang, D., Uluc, A., 2016. Macroprudential Policy in an Agent-Based Model of the UK Housing Market. Bank of England Staff Working Paper, p. 619.

Baumeister, C., Benati, L., 2013. Unconventional monetary policy and the great recession - Estimating the impact of a compression in the yield spread at the zero lower bound. Int. J. Cent. Bank 9 (2), 165-212.

Bean, C., Broda, C., Ito, T., Kroszner, R., 2015. Low for Long? Causes and Consequences of Persistently Low Interest Rates, 17. Geneva Reports on the World Economy.

Berger, A., Udell, G., 1994. Did risk-based capital allocate bank credit and cause a "Credit Crunch" in the United States. J. Money Credit Banking 26 (3), 585-628.

Bezemer, D., Hudson, M., 2016. Finance is not the economy: reviving the conceptual distinction. J. Econ. Issues 50 (3), $745-768$.

Bikker, J.A., Hu, H., 2002. Cyclical patterns in profits, provisioning and lending of banks and procyclicality of the new Basel capital requirements. Banca Nazionale Del Lavoro Q. Rev. 55 (221), 143-175.

Blundell-Wignall, A., Roulet, C., 2013. Bank lending puzzles. OECD J. 2013 (1), 7-30 2013.

Borio, C., Zhu, H., 2012. Capital regulation, risk-taking and monetary policy: a missing link in the transmission mechanism. J. Financ. Stability 8 (4), $236-251$.

Bowman, D., Cai, F, Davies, S., Kamin, S., 2011. Quantitative easing and bank lending: evidence from Japan. Int. Finance Discuss. Papers 57 (101), 1-33.

Brunnermeier, M.K., Sannikov, Y., 2014. A macroeconomic model with a financial sector. Am. Econ. Rev. 104 (2), 379-421.

Brunnermeier, M.K., Crockett, A., Goodhart, C.A., Shin, H.S., 2009. The Fundamental Principles of Financial Regulation. Geneva Reports on the World Economy, CEPR.

Buiter, W., 2009. "The unfortunate uselessness of most 'state of the art' academic monetary economics Available at www.voxeu.org/index.php?q=node/3210 accessed 20 October 2014

Cecchetti, S. and E. Kharroubi (2015): Why does financial sector growth crowd out real economic growth?, CEPR Discussion Paper 10642.

Chen, H., Cúrdia, V., Ferrero, A., 2011. The Macroeconomic Effects of Large-Scale Asset Purchase Programs, 527. FRB of New York Staff Report December 1, 2011.

Chodorow-Reich, G., 2014. Effects of unconventional monetary policy on financial institutions. Brookings Pap. Econ. Act. 2014 (1), $155-227$.

Churm, R., Radia, A., Leake, J., Srinivasan, S., Whisker, R., 2012. The funding for lending scheme. Bank Engl. Q. Bull. 52 (4), PP306-PP320.

Colander, D., Follmer, Goldberg, H., Haas, A., Juselius, K., Kirman, A., Lux, T., Sloth, B., 2009. The financial crisis and the systemic failure of the economics profession. Crit. Rev. 21 (2-3), 249-267.

Dawid, H. and DelliGatti, D., Agent-based macroeconomics (January 2018). Bielefeld Working Paper. Economics and Management. No. 02-2018

D’Amico, S., King, T.B., 2013. Flow and stock effects of large-scale treasury purchases: evidence on the importance of local supply. J. Financ. Econ. 108 (2), $425-448$.

DelliGatti, D., Gaffeo, E., Gallegati, M., Giulioni, G., Palestrini, A., 2008. Emergent macroeconomics: an agent-based approach to business fluctuations. Science 113.

DelliGatti, D., Gaffeo, E., Gallegati, M., 2010. Complex agent-based macroeconomics: a manifesto for a new paradigm. J. Econ. Interact. Coord, 5 (2), 111-135.

Easterly, W., Islam, R., Stiglitz, J.E., 2001. Shaken and stirred: explaining growth volatility. Annual World Bank Conference on Development Economics.

Fried, J, Wang, C, 2018. Are buybacks really shortchanging investment? Harvard Bus. Rev. 88-95 March-April.

Furfine, C., 2000. Evidence on the response of US banks to changes in capital requirements. Bank Int. Settlements 88, 1-32.

Furfine, C., Groeneveld, H., Hancock, D., Jones, D., Perraudin, W., Radecki, L., Yoneyama, M., 1999. Capital Requirements and Bank Behaviour: the Impact of the Basle Accord. Bank for International Settlements.

Gaffeo, E., DelliGatti, D., Desiderio, S., Gallegati, M., 2008. Adaptive microfoundations for emergent macroeconomics. East. Econ. J. 34 , $441-463$.

Gagnon, J., Raskin, M., Remache, J., Sack, B.P., 2011. Large-scale asset purchases by the Federal Reserve: did they work. SSRN Electron. J.

Gambacorta, L., Marques-Ibanez, D., 2011. The bank lending channel: lessons from the crisis. Econ. Pol. 26 (66), 135-182.

Gambacorta, L., Mistrulli, P.E., 2004. Does bank capital affect lending behavior. J. Financ. Intermediation 13 (4), $436-457$.

Goodhart, C., Ashworth, J.P., 2012. QE: a successful start may be running into diminishing returns. Oxford Rev. Econ. Policy 28 (4), 640-670.

Haldane, A., Roberts-Sklar, M., Wieladek, T., and Young, C., QE: the story so far (2016), Bank of England Working Paper, 624. 
Harada, Y., Minoru, M., 2009. Effectiveness and transmission mechanisms of Japan's quantitative monetary easing policy. Jpn. Econ. 36 (1), PP48-P105 Spring 2009.

Heid, F., Porath, D., and Stolz, S. (2004). Does capital regulation matter for bank behaviour. Evidence for German savings banks. Frankfurt am Main: Deutsche Bundesbank. Discussion Paper Series 2: Banking and Financial Supervision No 03/2004.

Honda, Y., Kuroki, Y., Tachibana, M., 2013. An Injection of Base Money at Zero Interest Rates. In: An Injection of Base Money at Zero Interest Rates, 1. Graduate School of Economics and Osaka School of International Public Policy, pp. 1-24.

Jones, D., 2000. Emerging problems with the Basel Capital Accord: Regulatory capital arbitrage and related issues. J. Bank. Finance 24 (1-2), 35-58.

Jordà, Ò., Schularick, M., Taylor, A.M., 2016. The great mortgaging: housing finance, crises and business cycles. Econ. Policy 31 (85), $107-152$.

Joyce, M.A.S., Liu, Z., Tonks, I., 2014. Institutional Investor Portfolio allocation, Quantitative Easing and the Global Financial Crisis. Bank of England Working Paper, p. 510.

Joyce, M.A.S., Spaltro, M., 2014. Quantitative easing and bank lending: a panel data approach. Bank of England Working Paper, p. 504.

Joyce, M.A.S., Tong, M., 2012. Qe and the gilt market: a disaggregated analysis. Econ. J. 122 (564), F271-F288.

Joyce, M., Tong, M., Woods, R., 2011b. The United Kingdom's quantitative easing policy: design, operation and impact. Bank Engl. Q. 3, 200-212.

Kapetanios, G., Mumtaz, H., Stevens, I., Theodoridis, K., 2012. Assessing the economy-wide effects of quantitative easing. Econ. J. 122 (564).

Kimura, T., Small, D.H., 2007. Quantitative monetary easing and risk in financial asset markets. BE J. Macroecon. 6 (1), 1-54.

Kirman, A., 2006. Demand theory and general equilibrium: from explanation to introspection, a journey down the wrong road. Hist. Pol. Econ. 38 (Suppl 1), 246-280.

Kirman, A., 2010. The economic crisis is a crisis for economic theory. CESifo Econ. Stud. 56 (4), 498-535.

Krugman, P., 2000. Thinking about the liquidity trap. J. Jpn.Int. Econ. 14 (4), 221-237.

Krugman, P.R., Dominquez, K.M., Rogoff, K., 1998. It's Baaack: Japan's slump and the return of the liquidity trap. Brookings Pap. Econ. Act. 1998 (2), 137.

Lengnick, M., 2013. Agent-based macroeconomics: a baseline model. J. Econ. Behav. Org. 86, 102-120.

Markose, S., Oluwasegun, B., Giansante, S., 2012. Multi-Agent Financial Network (MAFN) model of US collateralized debt obligations (CDO): regulatory capital arbitrage, negative CDS carry trade and systemic risk analysis. In: Alexandrova-Kabadjova, B, Martinez-Jaramillo, S, Garcia-Almanza, AL, Tsang, E. (Eds.), Simulation in Computational Finance and Economics: Tools and Emerging Applications. IGI Global August 2012.

Markose, S.M., 2013. Systemic risk analytics: a data-driven multi-agent financial network (MAFN) approach. J. Bank. Regul. 14 (3-4), $285-305$.

Mclaren, N., Banerjee, R.N., \&Latto, D., 2014. Using changes in auction maturity sectors to help identify the impact of QE on gilt yields. Econ. J., 124 (576), 453-479.

Oda, N., Ueda, K., 2007. The effects of the bank of Japan's zero interest rate commitment and quantitative monetary easing on the yield curve: a macro-finance approach. Jpn. Econ. Rev. 58 (3), 303-328.

Rajan, R.G., 2010. Rebalancing the global economy. New Perspectives Quarterly 27 (4), 7-9.

Reis, R., Balloch, C., Castillo-Martinez, L., 2016. Funding Quantitative Easing to Target Inflation. Designing Resilient Monetary Policy Frameworks for the Future.

Repullo, R., 2013. Cyclical adjustment of capital requirements: a simple framework. J. Financ. Intermediation 22 (4), 608-626.

Repullo, R., Suarez, J., 2013. The procyclical effects of bank capital regulation. Rev. Financ. Stud. 26 (2), $452-490$.

Reuters, 2013. Bond-backed stock buybacks remain in vogue Bond News, September 6, 2013. Available at https://www.reuters.com/article/ bonds-share-repurchases/bond-backed-stock-buybacks-remain-in-vogue-idUSL6N0H23BF20130906.

Rime, B., 2001. Capital requirements and bank behavior: empirical evidence for Switzerland. J. Bank. Finance 25, 789-805.

Rizzi, Joesph, 2013. “Calculate cost of equity to truly measure a bank's performance Available from American Banker website http://www.americanbanker. com/bankthink/calculate-cost-of-equity-to-truly-measure-a-banks-performance-1063099-1.html accessed 20 February 2015

Sargent, R.G., 2013. Verification and validation of simulation models. J. Simulation 7 (1), 12-24.

Stiglitz, J.E., 2011. Rethinking macroeconomics: what failed, and to how repair it. J. Eur. Econ. Assoc. 9 (4), $591-645$.

Stockhammer, E., 2004. Financialisation and the slowdown of accumulation. Cambridge J. Econ. 28 (5), 719-741.

Teglio, A., Raberto, M., Cincotti, S., 2012. The impact of banks' capital adequacy regulation on the economic system: an agent-based approach. Adv. Complex Syst. 15 (SUPP02), 1250040.

Thakor, A.V., 1996. Capital requirements, monetary policy, and aggregate bank lending: theory and empirical evidence. J. Finance 51 (1), $279-324$.

Washington Post, 2018. Beware the mother of all credit bubbles Available at https://www.washingtonpost.com/business/economy/beware-the-motherof-all-credit-bubbles/2018/06/08/940f467c-69af-11e8-9e38-24e693b38637_story.html?noredirect=on\&utm_term=.95b5f369806f.

Yahoo Finance, 2016. Companies are increasingly buying back stock with borrowed money Available at https://finance.yahoo.com/news/share-buybacksdebt-funding-000000439.html?guccounter=1.

Watanabe, W., 2007. Prudential regulation and the "credit crunch": evidence from Japan. J. Money Credit Bank. 39 (2-3), $639-665$.

Wieland, Volker, 2010. "Model Comparison and Robustness: A Proposal For Policy Analysis After the Financial Crisis. Goethe University of Frankfurt and IMFS.

Windrum, P., Fagiolo, G., Moneta, A., 2007. Empirical validation of agent based models : alternatives and prospects. J. Artif. Societies Soc. Simul. 10 (2007), $1-21$. 